\title{
The influence of hydrochar from biogas digestate on soil improvement and plant growth aspects
}

\author{
Megan de Jager ${ }^{1}\left[\right.$ D $\cdot$ Michael Röhrdanz ${ }^{1} \cdot$ Luise Giani $^{1}$
}

Received: 20 January 2020 / Accepted: 12 May 2020 / Published online: 3 June 2020

(c) The Author(s) 2020

\begin{abstract}
Hydrochar (HC), produced by hydrothermal carbonization, offers technical advantages over biochar (BC) produced by pyrolysis, and is suitable for soil amelioration, carbon sequestration, and enhanced plant growth. $\mathrm{BC}$ grain size has been shown to influence nutrient retention, microbial colonization and aggregate formation; however, similar research for $\mathrm{HC}$ is lacking. Pot trials were conducted to investigate the influence of $\mathrm{HC}$ grain size [coarse $(6.3-2 \mathrm{~mm})$, medium $(2-0.63 \mathrm{~mm})$ and fine $(<0.63 \mathrm{~mm})$ ], produced from biogas digestate, for soil improvement in three soils: loamy Chernozem, sandy Podzol, and clayey Gleysol, at a 5\% HC application rate (w/w). All soils including two controls (with and without plants) were analysed for water holding capacity (WHC), cation exchange capacity (CEC), wet aggregate stability, pH, plant available nutrients $\left(\mathrm{PO}_{4}-\mathrm{P}, \mathrm{K}\right.$ and $\left.\mathrm{N}_{\mathrm{min}}\right)$ and germination and biomass success using standard laboratory and statistical methods. Soil $\mathrm{pH}$ showed a compensatory shift toward the $\mathrm{HC} \mathrm{pH}$ (7.2) in all soils over the course of the study. For example, the $\mathrm{pH}$ of the medium grained HC treatment for the Chernozem decreased from 7.9 to 7.2 and increased in the Podzol and Gleysol from 5.9 to 6.1 and 4.9 to 5.5, respectively. The nutrient-rich $\mathrm{HC}\left(2034 \pm 38.3 \mathrm{mg} \mathrm{kg}^{-1} \mathrm{PO}_{4}-\mathrm{P}\right.$ and $2612.5 \pm 268.7 \mathrm{mg} \mathrm{kg}^{-1}$ $\mathrm{K}$ content) provided only a short-term supply of nutrients, due to the relatively easily mineralized fraction of $\mathrm{HC}$, which allowed for quick nutrient release. The $\mathrm{pH}$ and $\mathrm{PO}_{4}-\mathrm{P}$ effects were most pronounced in the fine grained $\mathrm{HC}$ treatments, with $\mathrm{a} \sim 87 \%, \sim 308 \%$ and $\sim 2500 \%$ increase in $\mathrm{PO}_{4}-\mathrm{P}$ content in the Chernozem, Podzol and Gleysol, respectively, compared to the controls at the beginning of the study. The same trend was observed for the $\mathrm{K}$ and $\mathrm{NH}_{4}{ }^{+}$content in the fine and medium grained $\mathrm{HC}$ treatments in all soils. No seed germination inhibition of Chinese cabbage was observed, with average germination rates $>50 \%$ in all soils. An effect on $\mathrm{NO}_{3}{ }^{-}$content was indeterminable, while there was little to no effect on biomass production, WHC, CEC and aggregate stability. In conclusion, the application of 5\% fine grained HC significantly influenced the nutrient content over a short-term. However, the application rate was insufficient to substantially improve plant growth, nor to sustain a longer-term nutrients supply, regardless of grain size.
\end{abstract}

Keywords Hydrochar · Soil improvement · Grain size · Plant available nutrients

\section{Introduction}

Intensified agricultural and energy production resulting from increasing global demands on resources such as energy, food and land have seen deleterious consequences for the global climate and soils through, inter alia, increased greenhouse gas (GHG) emissions and reduced soil quality. Poor agricultural practices and land use changes disturb the soil organic carbon (SOC) pool and liberate carbon dioxide $\left(\mathrm{CO}_{2}\right)$ from

Megan de Jager

megan.de.jager@uni-oldenburg.de

1 Carl Von Ossietzky Universität, Institut für Biologie und Umweltwissenschaften, Oldenburg, Germany the soil, thus contributing to the addition of GHGs into the atmosphere and decreasing soil quality and its resistance to stresses (Jones et al. 2015). A potential remedial measure to the problems of reduced soil quality may lie in the improvement and protection of the SOC pool through soil amendment.

The highly fertile Terra Preta de Indio soils of the Amazon Basin attribute their high carbon (C) content to the deliberate addition of charcoal-like materials over thousands of years by the prehistoric local inhabitants as well as by long-term mulching and frequent burning practices (Glaser et al. 2002; Lehmann and Rondon 2006; Sombroek et al. 1993; Steiner et al. 2009a, b; WinklerPrins 2014). The link between these practices and the improved soil quality 
of these previously infertile tropical soils has conceptualized the use of biochar (BC), a C-rich charcoal, as a popular soil amendment and management tool. $\mathrm{BC}$ is produced by pyrolysis which mimics the natural formation of coal, whereby biomass is heated at temperatures between 400 and $850^{\circ} \mathrm{C}$ under dry and oxygen $(\mathrm{O})$-limited conditions. A large proportion $(\sim 50 \%)$ of the source materials' $\mathrm{C}$ content remains in the final product (Lehmann et al. 2006), which is proven to have a high resistance to microbial decomposition and mineralization, and thus decomposes at a much slower rate than that of the raw biomass from which it is produced (Steiner et al. 2009b).

This recalcitrance lowers the rate at which $\mathrm{C}$ fixed by photosynthesis is returned to the atmosphere, which subsequently improves the aggregate stability, water holding capacity (WHC), and fertility of soils through the associated net increase in soil C stocks (Woolf et al. 2010). However, pyrolysis is limited in its use of dry biomasses (Libra et al. 2011; Monlau et al. 2015), and therefore, has a substantial energy requirement if pre-drying of feedstocks is deemed necessary. Furthermore, during pyrolysis, $\sim 50 \%$ of the raw biomass $\mathrm{C}$ is released back into the atmosphere, thus contributing to GHG emissions (Lehmann et al. 2006). As such, the potential benefits of $\mathrm{BC}$ application for soil amendment are somewhat negated by the shortcomings of the production process. An alternative to $\mathrm{BC}$ by pyrolysis is hydrochar $(\mathrm{HC})$ produced by hydrothermal carbonization (HTC).

HTC is a thermochemical conversion process capable of converting wet and dry feedstocks in a single, closed, water-saturated system under elevated pressure ( $\leq 20 \mathrm{bar}$ ) and lower temperatures $\left(180-250^{\circ} \mathrm{C}\right)$ compared to pyrolysis, with a residence time of $\leq 12 \mathrm{~h}$. HTC produces a charcoallike material referred to as $\mathrm{HC}$ and wastewater as the endproducts (Fiori et al. 2014; Libra et al. 2011). The lower temperature requirement for HTC ensures that combustion does not occur during the conversion process, making it a $\mathrm{C}$-neutral process. Depending on the HTC process parameters, namely temperature, $\mathrm{HC}$ may retain as much as $60-84 \%$ of the raw biomass $\mathrm{C}$ compared to $50 \%$ for $\mathrm{BC}$. A potential limitation of the HTC process is that this higher C content typically comes at the expense of the total mass yield, which decreases with increasing $\mathrm{C}$ content at higher process temperatures (Basso et al. 2013). Furthermore, the higher pressure requirement of HTC means that the manufacturing costs of the HTC equipment may be more expensive, and it also increases the complexity and hazard risk of the process (Kambo and Dutta 2015).

The mass yield of char produced by HTC is also a function of the heating rate, whereby slower heating rates coupled with lower maximum temperatures and increased pressure result in greater mass yields (Zhang et al. 2008; Septien et al. 2018). The heating rate also strongly influences the pore size and specific surface area (SSA) of the resultant char. It has been shown that slower heating rates typically produce micropores and higher SSA, while faster rates increase the macropore content of the char (Downie et al. 2009; Septien et al. 2018). The consequent SSA is an important consideration, as it has been linked to a higher $\mathrm{C}$ mineralization due to increased availability to microorganisms, especially in digestate-derived HC (Eibisch et al. 2013).

The potential limitations of the HTC process (as mentioned above) are overshadowed by its ability to process wet feedstocks (with water contents of $\geq 70 \%$ ), which broadens the possible biomass types that may be utilized to include unconventional feedstocks such as biogas digestate and wet animal manures (Libra et al. 2011). This advantage is particularly important in areas of high agricultural production, where excessive waste is problematic. A boom in the establishment of biogas plants over the past 20 years (Theuerl et al. 2019) has resulted in an excess of the by-product, biogas digestate (Marchetti and Castelli 2013), which is commonly used as fertilizer (Garlapalli et al. 2016). Consequently, the amount produced surpasses fertilizer demands, thus classifying it as agricultural waste. HTC of biogas digestate produces a solid product with a higher $\mathrm{C}$ content than the source materials, which allows for easier storage and transportation to areas where fertilization is required (Kambo and Dutta 2015; Eskandari et al. 2019).

Pyrolysis and HTC process conditions and source materials influence the characteristics of the final product, and consequently its recalcitrance and efficiency as a soil amendment tool. These determinant parameters (e.g. feedstock type and process conditions) for the intended application of BC can be manipulated to design a product with specific characteristics, i.e. structure and size. The application of $\mathrm{BC}$ to soils has shown to improve the properties of the soils by increasing the WHC and cation exchange capacity (CEC), with improved nutrient dynamics and microbial activity, which subsequently stimulates plant growth and improves plant health (Brodowski et al. 2005; Glaser et al. 2002; Hagemann et al. 2016; Liu et al. 2017; Schulz and Glaser 2012; Verheijen et al. 2009). A meta-analysis of over 300 studies by Biederman and Harpole (2013) found that, on average, the addition of $\mathrm{BC}$ increased above ground biomass production, soil phosphorous $(\mathrm{P})-$, potassium $(\mathrm{K})$ - and total $\mathrm{C}$ - and nitrogen $(\mathrm{N})$ content and increased the $\mathrm{pH}$ of acidic soils, regardless of soil type and climatic conditions.

The grain size of the applied $\mathrm{BC}$ holds implications for its intended effects on the soil, due to their arrangement within the soil particle matrix and the consequent alteration of the soil pore size distribution. The size of the BC particles applied to soil together with the inherent porosity and surface area influence the bioavailability of nutrients, the accessibility of microbial communities to the pores for colonization, water storage and mobility, and the degree 
of oxidation that takes place on the surface of the BC particles, which have further ramifications for aggregate formation and soil stability (Brodowski et al. 2005; Hagemann et al. 2016; Liu et al. 2017; Verheijen et al. 2009). The addition of small grained $\mathrm{BC}$ particles $(<0.5 \mathrm{~mm})$ increases soil aggregation and water retention through a greater SSA, compared to larger BC particles (BlancoCanqui 2017; de Jesus et al. 2019; Głąb et al. 2016).

The above stated impacts on soil properties are all reported in studies pertaining to BC produced by pyrolysis. Presumably, the addition of HC would have similar effects, due to its similarities (namely, the high $\mathrm{C}$ content) with BC. However, HC differs from BC in its physical and chemical structure, which holds implications for their intended purposes (Busch and Glaser 2015; Libra et al. 2011). Compared with BC, HC has a higher hydrogen $(\mathrm{H}) / \mathrm{C}$ and $\mathrm{O} / \mathrm{C}$ ratio, lower porosity and poorer surface area, and the surface functionalities between the chars differ considerably (Kambo and Dutta, 2015; Libra et al. 2011). Such differences highlight the fact that the known impacts of BC cannot simply be inferred for $\mathrm{HC}$ as well.

In addition to the relatively limited studies of the impacts of $\mathrm{HC}$ on soil properties, its influence on plant growth dynamics is also an important consideration. A study by Bargmann et al. (2014b) showed that the addition of HC initially inhibited seed germination of barley, but this effect was diminished after nine weeks, likely due to microbial decomposition. It was suggested that this decomposition was indirectly facilitated by the dissolved organic carbon (DOC) content of the HC, which stimulated microbial growth (Gronwald et al. 2015; Hao et al. 2018). The transient nature of this effect was also evinced by Sun et al. (2014) and Mukherjee et al. (2016). Related studies by Prayogo et al. (2014) found that SOC mineralization was reduced in soils amended with $\mathrm{HC}$, due to the preferential utilization of the soluble $\mathrm{C}$ fraction of the $\mathrm{HC}$ by soil microbes. Contrarily, Fang et al. (2015) saw no significant influence on seed germination by $\mathrm{HC}$ addition, while Puccini et al. (2018) found a significant reduction in the germination success of lettuce using fresh- and posttreated $\mathrm{HC}$.

With regards to plant growth, Baronti et al. (2017) found a significant increase in the biomass production of poplar trees with $\mathrm{HC}$ addition after two consecutive years, while Bargmann et al. (2014b) showed no negative effects on spring barley at a $4 \% \mathrm{HC}$ application rate. Furthermore, Schimmelpfennig et al. (2014) saw a substantial reduction in plant growth with the field application of $\mathrm{HC}$, particularly in the first year of the experiment. However, HTC is a relatively modern carbonization method and research regarding the effectiveness of $\mathrm{HC}$ for soil amendment and plant growth is disproportionate compared to $\mathrm{BC}$, and such information remains limited.
Based on existing and available information, we therefore hypothesize that the addition of $\mathrm{HC}$ will: (a) improve soil properties essential to plant growth; (b) impact the soil properties differently based on the grain size of the applied HC; (c) initially inhibit seed germination (based on Bargmann et al. 2014a; Röhrdanz et al. 2019; Steiner et al. 2009b); and (d) enhance biomass production due to an improved soil quality.

The objectives of this study test these hypotheses by analysing the overall influence of HC application on soil improvement, germination success and biomass production as well as with respect to different $\mathrm{HC}$ grain sizes. Three soil types were studied: Chernozem, Podzol and Gleysol, which were selected based on their dissimilar properties. To the authors' best knowledge, no existing studies focus on the effect of grain size of $\mathrm{HC}$ on soil amendment, seed germination and biomass production.

To achieve these objectives, the following research questions were posed:

1. Does the addition of $\mathrm{HC}$ improve the soil properties essential to plant growth, such as WHC, CEC, pH, aggregate stability and nutrient contents?

2. Does the grain size of the applied $\mathrm{HC}$ affect its influence on soil properties?

3. How does HC application affect seed germination and biomass production of Chinese cabbage?

By answering these questions, this study will substantially contribute to our relatively rudimentary understanding of $\mathrm{HC}$ as a promising amendment product.

\section{Materials and methods}

\subsection{Experimental design}

The soils used in this study were collected from conventionally operating farms in December 2017. The sampling sites of the Chernozem and Podzol are under long-term arable use, and are located within the Hohe Börde Municipality in Saxony-Anhalt, Germany (52 $\left.10^{\circ} 35^{\prime \prime} \mathrm{N}, 11^{\circ} 30^{\prime} 42^{\prime \prime} \mathrm{E}\right)$, and the Bruchhausen-Vilsen Municipality in Lower Saxony, Germany ( $\left.52^{\circ} 48^{\prime} 35^{\prime \prime} \mathrm{N}, 8^{\circ} 59^{\prime} 41^{\prime \prime} \mathrm{E}\right)$, respectively. The Gleysol was sampled within the Ovelgönne Municipality in

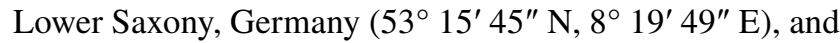
the site is under grassland conditions. The Chernozem may be classified as a silty clay (particle size distribution: $16 \%$ sand, $43 \%$ silt, $41 \%$ clay), the Podzol a sandy loam (66\% sand, $22 \%$ silt, $13 \%$ clay), and the Gleysol a clay (1\% sand, $6 \%$ silt, $93 \%$ clay). The samples were randomly collected from the upper $30 \mathrm{~cm}$ and were air-dried in the greenhouse before being ground to $<2 \mathrm{~mm}$ using a grinding mill. 
The HC was provided by Grenol GmbH (Meiersberg [Ratingen], Germany) and was produced from biogas digestate; carbonized at $\sim 200{ }^{\circ} \mathrm{C}, 18-20$ bar pressure, with a residence time at the maximum temperature of approximately $3 \mathrm{~h}$ and a heating and cooling time of $1.5 \mathrm{~h}$ each. This equates to a heating rate of ca. $2-3{ }^{\circ} \mathrm{C}$ per min by constant heating, while the cooling rate could not be specified as it is dependent on the ambient temperature of the surroundings of the batch reactor. The digestate source material was derived from corn, sugar beets and beef- and liquid-swine manure. It was not pre- or post-treated for any specification and was air-dried and pressed into briquettes after conversion for transportation.

The HC briquettes were manually broken into smaller pieces using a hammer and then sieved into three grain size classes, namely, a coarse grained $(6.3-2 \mathrm{~mm})$, medium grained $(2-0.63 \mathrm{~mm})$ and fine grained $(<0.63 \mathrm{~mm})$ fraction. At an application rate of $5 \%(\mathrm{w} / \mathrm{w})$, the $\mathrm{HC}$ was then manually homogenously mixed with the soils, before placing the mixtures into pots of $\sim 13 \mathrm{~cm}$ diameter (ca. 1 litre [1] volume). A mesh material was placed over openings at the bottom of the pots to reduce soil loss. Seven pots for each $\mathrm{HC}$ grain size-soil mixture was used, as well as five control pots of original soil (no $\mathrm{HC}$ added) which were sown with Chinese cabbage seeds. Additional five control pots of original soil were kept devoid of seeds. All experiments were conducted in a greenhouse in a non-climate controlled environment.

\subsubsection{Seed germination experiment}

Two rounds of seed germination experiments were carried out to determine whether any germination inhibition effects may result from the addition of $\mathrm{HC}$, as reported in numerous studies (Bargmann et al. 2014a; Röhrdanz et al. 2019; Steiner et al. 2009b). The pots (except for the control devoid of plants for each soil) were planted with 25 Chinese cabbage seeds (Brassica rapa ssp. Pekinensis) and were watered manually based on plant requirement. Germination success was calculated as the percentage of germinated seeds (25 seeds $=100 \%$ ). At the conclusion of each round (ca. 3 weeks each) of the germination experiment, the plants were harvested from the pots before being sown with new seeds.

\subsubsection{Plant growth experiment}

Subsequent to the germination experiment, the plant growth experiment was conducted, which involved sowing each pot with four Chinese cabbage seeds. After approx. 4 weeks of growth, the number of plants was reduced to one per pot. The plants were grown for approx. 6 weeks from the start of the plant growth experiment, after which they were harvested (above ground biomass exclusively), and weighed before and after oven-drying at $105^{\circ} \mathrm{C}$ to constant weight to determine the total biomass for each treatment (HC grain size-soil mixture) and control.

\subsection{Soil analyses}

Control samples were collected from each soil prior to the addition of $\mathrm{HC}$, which are hereinafter referred to as Time 0 $\left(T_{0}\right)$ samples. Samples were collected immediately after mixing the $\mathrm{HC}$ with the soils at the beginning of the study for soil property analyses, which are hereinafter referred to as Time $1\left(T_{1}\right)$ samples. At the end of the plant growth experiment, samples were collected destructively from each pot for each respective treatment and control. The seven samples from each grain size treatment and five samples from each of the controls were mixed into respective composite samples, which were transported to the laboratory for soil property analyses. These samples collected at the end of the experiment are hereinafter referred to as Time $2\left(T_{2}\right)$ samples. The samples were air-dried and sieved $<2 \mathrm{~mm}$ for all soil property analyses. Extractions and measurements for soil property analyses were conducted approx. 3-4 weeks after sampling at $T_{2}$.

Particle size distribution was determined by a combination of mechanical sieving and sedimentation with Atterberg cylinders, after removal of carbonates, organic matter (OM) and iron $(\mathrm{Fe})$ oxides. Soil textural classes were determined based on the Food and Agriculture Organization of the United Nations (FAO 2006) soil taxonomy system. The $\mathrm{pH}$ was determined in a $1 \mathrm{~g}: 2.5 \mathrm{ml}$ soil-to-distilled water $\left(\mathrm{H}_{2} \mathrm{O}\right)$ solution, after manual stirring at $15 \mathrm{~min}$ intervals for $1 \mathrm{~h}$.

Given the nature of the material (the presence of HC), procedural modifications were required for the determination of the WHC and CEC. The WHC was determined using a filtration method adapted from Alef (1991), as described in Röhrdanz et al. (2016). The potential CEC $\left(\mathrm{CEC}_{\text {pot }}\right)$ was determined using a modified extraction method, after Sänger-von-Oepen et al. (1993), Handbuch Forstliche Analytik (2005), and VDLUFA (2012a).

Mineral nitrogen (Nmin), in the form of ammonium $\left(\mathrm{NH}_{4}{ }^{+}\right)$and nitrate $\left(\mathrm{NO}_{3}{ }^{-}\right)$, was determined by the standard Nmin laboratory method (DIN 19746), according to VDLUFA (2002). The plant available $\mathrm{P}$ and $\mathrm{K}$ were determined using the calcium $(\mathrm{Ca})$-acetate-lactate extraction method (VDLUFA 2012b), at a concentration of $0.6 \%$. This solution was buffered to a $\mathrm{pH}$ of 3.6. The $\mathrm{P}$ concentration was determined colorimetrically as phosphate $\left(\mathrm{PO}_{4}-\mathrm{P}\right)$ using a coloring agent of $0.5 \%$ ascorbic acid and $1 \%$ ammonium heptamolybdate, measured by a spectrophotometer (Shimadzu UVmin-1240). The plant available K was measured by atomic absorption spectrometry. The water aggregate stability was determined using the wet sieving method, as 
described in Kalinina et al. (2011), and which is derived from Six et al. (2000).

\subsection{Elemental analysis}

The elemental composition of the $\mathrm{HC}$ was determined for $\mathrm{C}, \mathrm{H}, \mathrm{N}$ and sulphur (S) using a Euro Elemental Analyzer (Eurovector; HEKAtech $\mathrm{GmbH}$ ), after oven drying at $105^{\circ} \mathrm{C}$ (Schröter 2018). The ash content of the HC was determined as the amount of material remaining after dry oxidation at $550{ }^{\circ} \mathrm{C}$, according to DIN EN 14775:2010-04. The O content of the $\mathrm{HC}$ was calculated as the difference in the $\mathrm{C}, \mathrm{H}, \mathrm{N}$, $\mathrm{S}$ and ash content of the sample to $100 \%$, as illustrated in equation below:

$O[\%]=100 \%-C[\%]-H[\%]-N[\%]-S[\%]-A s h[\%]$

The elemental composition and ash content of the $\mathrm{HC}$ is provided in Table 1. These results were used to calculate the molar element ratios.

\subsection{Statistical analyses}

A normal distribution is a critical assumption in the use of a one-way analysis of variance (ANOVA). Due to the small number of replicates $(n=3)$ in this study, the normal distribution of the data could not be determined with confidence. Therefore, the non-parametric Kruskal-Wallis H test was applied for all residuals, following tests for normal distribution (Shapiro-Wilk test) and homogeneity of variance (Levene's test). Significant differences between groups were determined by the pairwise comparisons post-hoc test, using the procedure prescribed by Dunn (1964), with a Bonferroni correction for multiple comparisons $(p<0.05)$ (Laerd Statistics 2015). These statistical analyses were performed to determine significant differences between $\mathrm{HC}$ grain size treatments at each phase of the study $\left(T_{1}\right.$ and $\left.T_{2}\right)$. The biomass results were subjected to the ANOVA statistical test, and the normally distributed residuals further underwent a comparison of means post-hoc test (Scheffe test) to indicate significant differences $(p<0.01)$. It must be noted that only two replicates were measured for the WHC and CEC analysis, and therefore statistical analyses for these properties could not be performed.

To determine if the differences over the course of the study $\left(T_{0}\right.$ to $\left.T_{2}\right)$ between $\mathrm{HC}$ grain size treatments and controls were statistically significant, the independent-samples t-test was employed, following the Shapiro-Wilk test for normal distribution, and Levene's test of homogeneity of variances. If the assumption of homogeneity of variances was violated, the independent-samples t-test was calculated using separate variances and the Welch-Satterhwaite correction to the degrees of freedom (Laerd Statistics 2015). Significant differences are based on mean values. Statistical analyses were performed using SPSS 25.

\section{Results and discussion}

\subsection{Effect of hydrochar application on soil properties}

\subsubsection{Water holding capacity}

A sufficient water supply is essential for optimum plant growth. Hence, increasing WHC is a major driver for soil improvement, especially for coarse grained soils (e.g. Podzol), for which WHC is naturally notably low. Several studies stated a positive effect of $\mathrm{HC}$ addition on WHC, and furthermore, positive correlations between finer grained BC particles $(<0.25 \mathrm{~mm})$ and water content and retention have been noted by Liu et al. (2017) and de Jesus et al. (2019).

Our results for the controls (at $T_{0}$ ) show an initial average WHC of $0.9 \pm 0.1 \mathrm{~g} \mathrm{H}_{2} \mathrm{O} / \mathrm{g}$ dry soil $(\mathrm{g} / \mathrm{g}$ ) for the Chernozem; $0.7 \pm 0.1 \mathrm{~g} / \mathrm{g}$ for the Podzol; and $1.2 \pm 0.1 \mathrm{~g} / \mathrm{g}$ for the Gleysol. The minimum and maximum WHC values for the controls and HC amended soils are provided in Table 2. The average WHC of the HC was measured at $1.47 \mathrm{~g} / \mathrm{g}$, which is in line with other findings (Libra et al. 2011). A tendency of improved WHC shortly after the addition of HC (at $T_{1}$ ) was revealed in the Podzol. However, this initial increasing tendency did not persist throughout the course of the study. Post the three-month plant growth experiment $\left(T_{2}\right)$, no distinguishable trend between $\mathrm{HC}$ grain size and WHC was apparent for all soils, although a general decreasing tendency in WHC was observed for the amended soils from $T_{1}$ to $T_{2}$.

The increasing tendency in WHC observed mainly in the Podzol (sandy loam) at $T_{1}$ is supported by Abel et al. (2013) and Röhrdanz et al. (2016), who have shown that the potential for increasing WHC is greater in soils with lower WHC, such as sandy soils, due to the smaller SSA and lower microporosity of sandy (coarse) textured soils compared to
Table 1 Elemental composition and ash content of the hydrochar produced from biogas digestate (Schröter 2018)

\begin{tabular}{llllllllll}
\hline & $\mathrm{C}$ & $\mathrm{H}$ & $\mathrm{N}$ & $\mathrm{S}$ & $\mathrm{O}$ & Ash content & \multicolumn{2}{l}{ Molar element ratio } \\
\cline { 6 - 9 } & Weight $(\%)$ & & & & & & $\mathrm{C} / \mathrm{N}$ & $\mathrm{H} / \mathrm{C}$ & $\mathrm{O} / \mathrm{C}$ \\
\hline $\begin{array}{l}\text { Biogas digestate } \\
\text { hydrochar }\end{array}$ & 35.2 & 3.8 & 2.7 & 0.9 & 10.2 & 47.2 & 15.2 & 1.3 & 0.2 \\
\hline
\end{tabular}


Table 2 Minimum and maximum water holding capacity (WHC) for controls and hydrochar amended soils over the course of the study in Chernozem, Podzol and Gleysol soils

\begin{tabular}{|c|c|c|c|c|c|c|c|c|c|}
\hline \multirow[t]{3}{*}{ Soil } & \multicolumn{4}{|c|}{ Beginning of experiment } & \multicolumn{5}{|c|}{ End of experiment } \\
\hline & \multirow{2}{*}{$\begin{array}{l}T_{0} \\
\text { Control }\end{array}$} & \multicolumn{3}{|l|}{$T_{1}$} & \multicolumn{5}{|l|}{$T_{2}$} \\
\hline & & Coarse & Medium & Fine & Control & Control_pl ${ }^{\mathrm{a}}$ & Coarse & Medium & Fine \\
\hline \multicolumn{10}{|l|}{$\mathrm{g} / \mathrm{g}$} \\
\hline Chernozem & $0.88-0.97$ & $0.94-0.97$ & $0.89-0.97$ & $0.96-1.03$ & $0.85-1.1$ & $0.86-0.94$ & $0.86-0.9$ & $0.85-0.87$ & $0.86-0.87$ \\
\hline Podzol & $0.63-0.73$ & $0.74-0.84$ & $0.74-0.84$ & $0.74-0.8$ & $0.7-0.7$ & $0.68-0.73$ & $0.72-0.75$ & $0.68-0.74$ & $0.67-0.73$ \\
\hline Gleysol & $1.14-1.27$ & $1.16-1.22$ & $1.28-1.29$ & $1.19-1.20$ & $1.07-1.12$ & $1.13-1.22$ & $1.03-1.06$ & $1.07-1.12$ & $1.09-1.12$ \\
\hline
\end{tabular}

WHC of hydrochar $=1.47 \mathrm{~g} / \mathrm{g}$

${ }^{a}$ Control with plant

more clay-rich soils (Blanco-Canqui 2017). Liu et al. (2017) attributed this improvement (in sandy soils especially) to the change in pore structure and pore space dynamics induced by the addition of BC, which may also be relevant to $\mathrm{HC}$. However, the application rate of $5 \% \mathrm{HC}$ with a WHC of $1.47 \mathrm{~g} / \mathrm{g}$, as performed in this study, was not sufficient to significantly alter the pore distribution of the soils, and as such, could not substantially increase the WHC of the soils. The unexpected lack of HC influence on WHC may also be due to the hydrophobicity of the $\mathrm{HC}$, as shown by Berge et al. (2013), which may result when HC is air-dried (as in this study).

\subsubsection{Aggregate stability}

Aggregation alters the pore size distribution in soils and consequently, the air and water capacities. Aggregation is particularly prevalent in fine grained clayey soils, resulting in the formation of bigger pores and thus, substantially improving air and water balances. For BC, it was found that its addition improved aggregation (Pituello et al. 2018; Blanco-Canqui 2017).

The best proxy for aggregation is the Mean Weight Diameter (MWD), which indicates the relation between aggregate stability and size of aggregates, whereby a greater proportion of larger aggregates implies greater stability (Nimmo and Perkins 2002; Sun and Lu 2014). Of the controls at $T_{0}$, the Chernozem had an average MWD of $0.3 \pm 0.01 \mathrm{~mm}$; the Podzol, $0.2 \pm 0.01 \mathrm{~mm}$; and the Gleysol, $0.5 \pm 0.03 \mathrm{~mm}$ (Fig. 1). Shortly after HC application $\left(T_{1}\right)$, the MWD for the $\mathrm{HC}$ amended Gleysol showed no directed trend, but the HC amended Chernozem and Podzol appeared to increase compared to the respective controls. However, the variation in statistically significant differences between treatments and controls indicates the absence of a clear trend between the grain size of the added $\mathrm{HC}$ and aggregate stability at $T_{1}$. At the end of the study $\left(T_{2}\right)$, there were no significant differences between the controls and HC amended soils for all soils. However, over the course of the study $\left(T_{1}\right.$ to $\left.T_{2}\right)$, the
MWD of stable aggregates increased for all soils, but was only significantly different for all Chernozem and Gleysol samples, except the Chernozem coarse grained treatment

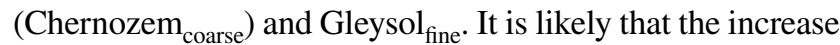
in MWD in the controls and $\mathrm{HC}$ amended soils during the course of the study (from $T_{1}$ to $T_{2}$ ) was the result of other factors, and therefore, no clear effect of HC on MWD was indicated in the results.

The lack of (a definitive) HC influence on soil aggregation at $T_{1}$ may not be surprising, as aggregate formation is dependent on, inter alia, biological activity and time. The increase in MWD of aggregates over the course of the study for the controls, as well as most of the HC amended soils, indicates that the $\mathrm{HC}$ is likely not responsible for the improved aggregation. More likely, the results point to the probability that the increase in MWD at $T_{2}$ was due to the formation of macroaggregates as part of the initial phases of soil restoration, following semi-destructive sampling (Kalinina et al. 2011).

\subsubsection{Soil pH}

The management and readjustment of $\mathrm{pH}$ are critical in soil amelioration practises. Where $\mathrm{pH}$ values are too acidic or alkaline, toxicities and limited nutrient availabilities may result. Due to general acidification processes in temperate soils, a good $\mathrm{pH}$ regulation may be achieved by the addition of liming materials. Similarly, the addition of $\mathrm{HC}$ has been found to alter soil $\mathrm{pH}$ (Malghani et al. 2015; Biederman and Harpole 2013), and hence, HC could considerably contribute to $\mathrm{pH}$ readjustment.

In this study, the initial average $\mathrm{pH}$ of the Chernozem ${ }_{\text {control }}$ was slightly alkaline $(7.9 \pm 0.1)$, while the Podzol ${ }_{\text {control }}$ and Gleysol $_{\text {control }}$ were more acidic $(5.8 \pm 0.1$ and $4.9 \pm 0.0$, respectively). Shortly after the addition of $\mathrm{HC}$ with $\mathrm{pH}$ $7.2 \pm 0.1$ at $T_{1}$, the Podzol and Gleysol showed a slight increasing shift in $\mathrm{pH}$, most pronouncedly in the fine grained $\mathrm{HC}$ treatments, while the $\mathrm{pH}$ of the Chernozem remained relatively unchanged. At the end of the study $\left(T_{2}\right)$, the $\mathrm{pH}$ of 
Fig. 1 Average Mean Weight Diameter (MWD) for the controls and hydrochar grain size treatments in a Chernozem, Podzol and Gleysol over the course of the plant growth experiment. Error bars represent standard deviation of the means. Different letters indicate significant differences in means at $p<0.05$ level between treatments at the respective time period. $n . s=$ nonsignificant. Solid bars indicate significant differences and patterned bars nonsignificant differences in means $(p<0.05)$ between treatments at the beginning $\left(T_{0}\right.$ and $\left.T_{1}\right)$ and end of the study $\left(T_{2}\right)$. Control_pl = control with plant

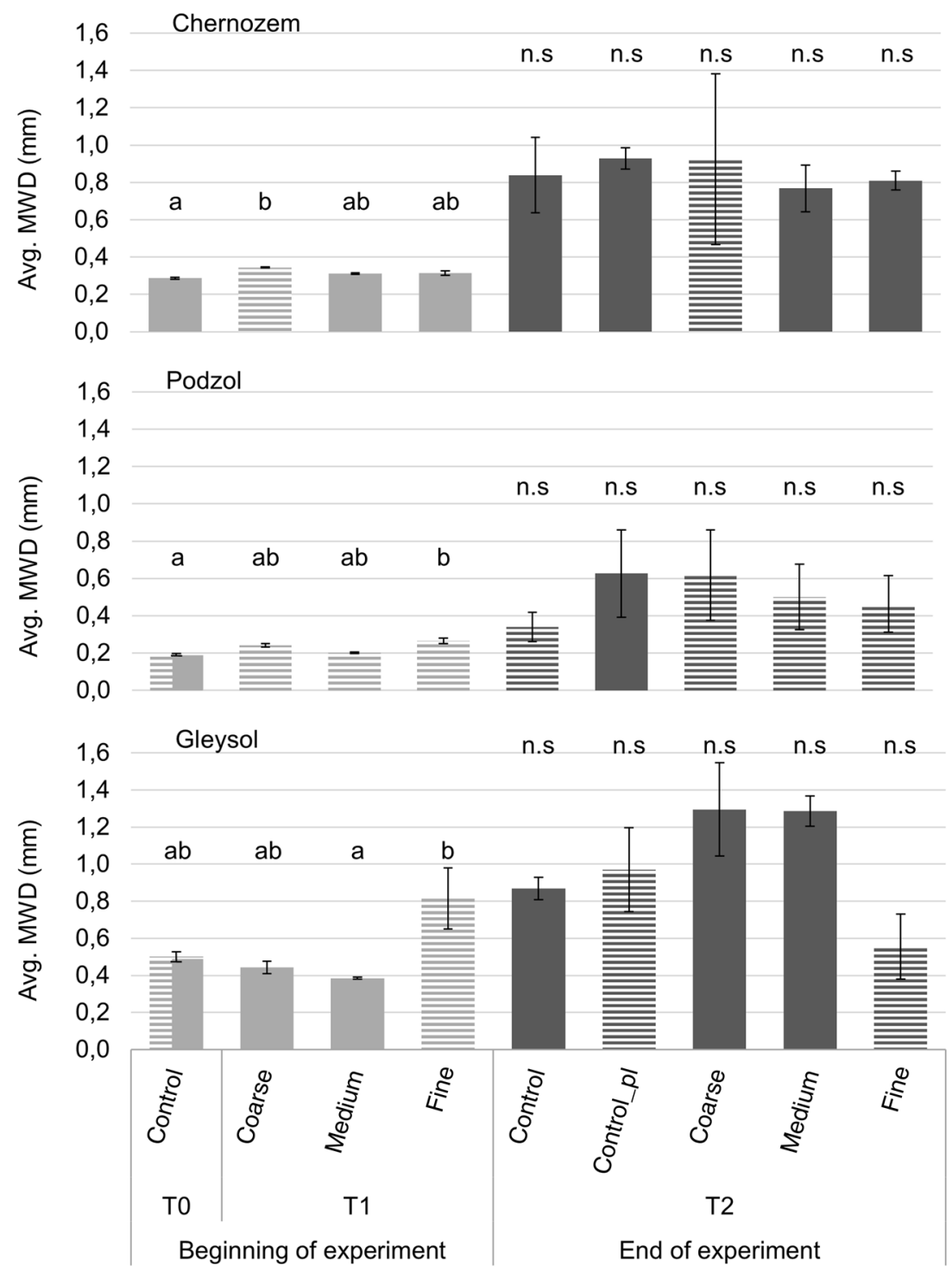

the $\mathrm{HC}$ amended Chernozem was lower than the controls, and furthermore, the Chernozem medium $_{\text {and Chernozem }}$ fine had reached the same $\mathrm{pH}$ as the HC (7.2) (see Fig. 2). Simultaneously, the trend of increasing $\mathrm{pH}$ in the amended Podzol and Gleysol continued, resulting in significant differences between the controls and amended soils, namely, the Podzol $\mathrm{P}_{\text {fine }}(p=0.040)$ and the Gleysol ${ }_{\text {medium }}(p=0.010)$. Therefore, it would appear that the addition of $\mathrm{HC}$ resulted in a shift of soil $\mathrm{pH}$ to the $\mathrm{pH}$ of the $\mathrm{HC}$, which was more prominent in the finer grained fractions.

These results are consistent with that of Malghani et al. (2015), where HC addition significantly increased the $\mathrm{pH}$ of a coarse grained acidic soil. A related study by Liao and Thomas (2019) found that the addition of small grained $(0.06-0.5 \mathrm{~mm})$ sieved BC to a granitic sand increased the $\mathrm{pH}$ by 0.3 units, compared to a larger grain size $(2-4 \mathrm{~mm})$, which showed no significant difference; thus confirming our findings in respect of grain size effects. Liao and Thomas (2019) further suggested that BC produced from feedstocks of smaller particle size, such as the decomposed plant material which constitutes part of the digestate from which the HC in this study was produced (Greenberg et al. 2019), have a higher ash content, thus promoting alkalinity.

The equilibration of the $\mathrm{pH}$ values of the soil and (finer grained) $\mathrm{BC}$ are suggested to be the result of increased physical contact between the soil and $\mathrm{BC}$ particles, as well as the high ash content of the $\mathrm{BC}$, which promotes the liming effect of the BC and its capacity to buffer soil acidity (Domingues et al. 2017) and provides additional cations to the soil, which increases $\mathrm{pH}$, particularly in sandy and loam textured soils (Glaser et al. 2002). As found for the Chernozem in this study, a reduction in soil $\mathrm{pH}$ was also possible when $\mathrm{HC}$ was added to a soil that had a higher $\mathrm{pH}$ than that of the HC. As such, this study's findings confirm that the conclusion of 
Fig. 2 Average $\mathrm{pH}$ (measured in distilled $\mathrm{H}_{2} \mathrm{O}$ ) for the controls and hydrochar grain size treatments in a Chernozem, Podzol and Gleysol over the course of the plant growth experiment. The solid line represents the $\mathrm{pH}$ of the HC (7.2). Error bars represent standard deviation of the means. Different letters indicate significant differences in means at $p<0.05$ level between treatments at the respective time periods. $\mathrm{n} . \mathrm{s}=$ nonsignificant. Solid bars indicate significant differences in means $(p<0.05)$ between treatments at the beginning and end of the study. Patterned bars $=$ nonsignificant. Control_pl $=$ control with plant
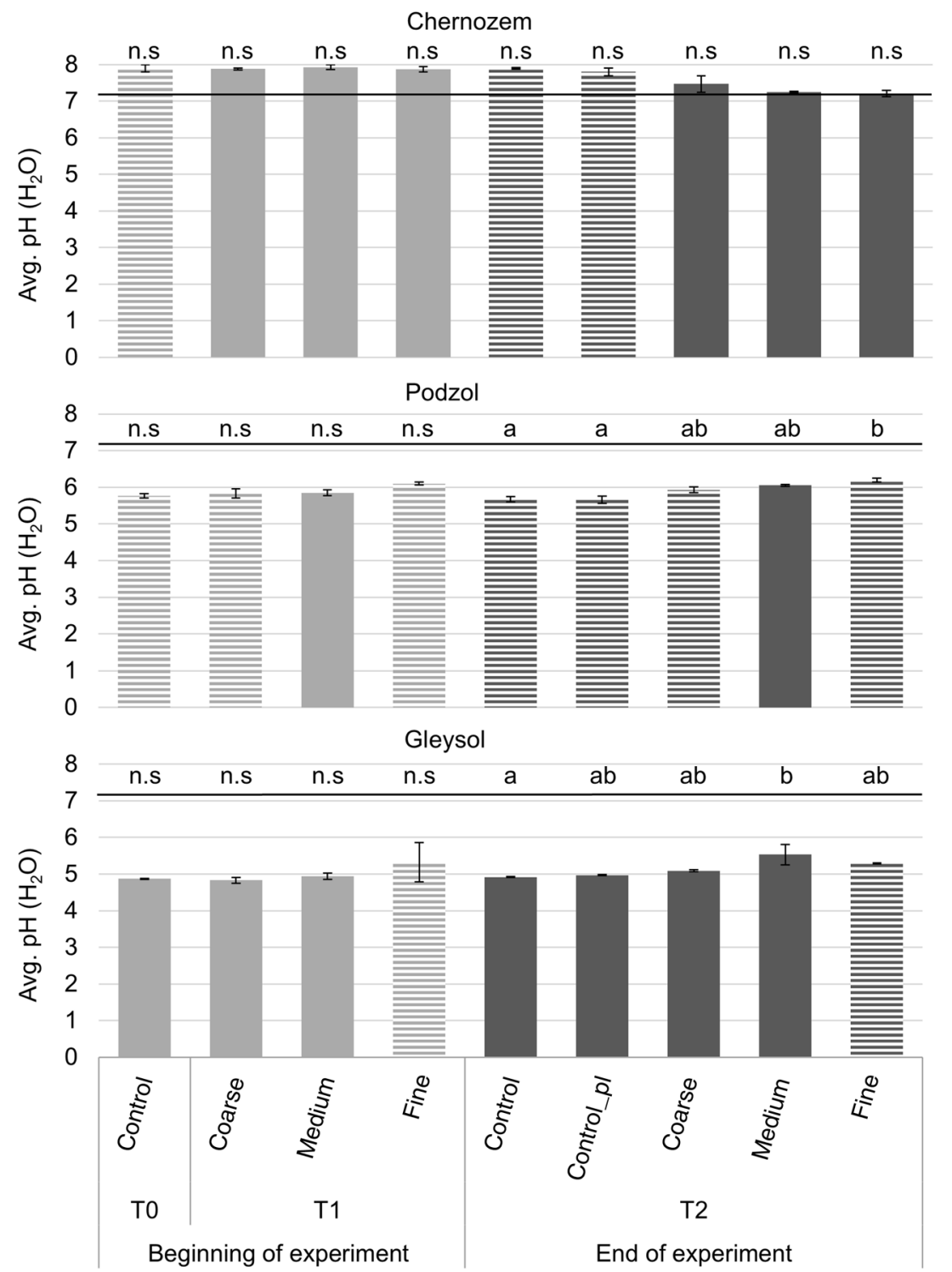

Biederman and Harpole (2013) may be inferred for $\mathrm{HC}$ as well, whereby the $\mathrm{pH}$ response is dependent on the initial $\mathrm{pH}$ of the soil, as well as the $\mathrm{pH}$ of the $\mathrm{BC} / \mathrm{HC}$ material.

\subsubsection{Potential cation exchange capacity $\left(\right.$ CEC $\left._{\text {pot }}\right)$}

CEC is a major controlling factor in the availability of plant nutrients. Hence, increasing the CEC of soils is of particular interest in the context of soil improvement, especially since increased CEC is coincident with higher fertilizer efficiency and the reduced entry of nutrient loads into groundwater systems (Bargmann et al. 2014a). BC typically has a high $\mathrm{CEC}$, and its addition to soils has shown to increase the soil CEC (Garlapalli et al. 2016). However, contradictory findings have been reported for HC. For example, Puccini et al. (2018) observed a very low CEC for fresh HC, while Salem (2013) report increased CEC of soils by HC addition.
Additionally, Libra et al. (2011) hypothesized that HC surface functional groups should improve soil CEC. Such variability leaves open questions regarding the sorption capacity of $\mathrm{HC}$ and its ability to improve soil CEC.

In this investigation, the $\mathrm{CEC}_{\text {pot }}$ of the Chernozem ${ }_{\text {control }}$ at the beginning of the study $\left(T_{0}\right)$ was $39.5 \pm 2 \mathrm{cmol}$ $\mathrm{kg}^{-1}$, for the Podzol ${ }_{\text {control }}, 18.8 \pm 2 \mathrm{cmol} \mathrm{kg}^{-1}$, and for the Gleysol $_{\text {control }}, 85.8 \pm 0.4 \mathrm{cmol} \mathrm{kg}^{-1}$ (Table 3). Shortly after $\mathrm{HC}$ addition $\left(T_{1}\right)$, the $\mathrm{CEC}_{\mathrm{pot}}$ remained relatively unchanged for all $\mathrm{HC}$ grain size treatments compared to the controls for all soils. The same result was found at the end of the study $\left(T_{2}\right)$, whereby a difference in $\mathrm{CEC}_{\text {pot }}$ between controls and $\mathrm{HC}$ amended soils remained indistinct. Hence, the results show no impact on $\mathrm{CEC}_{\text {pot }}$ by $\mathrm{HC}$ addition.

Schulz and Glaser (2012) argued that improved CEC by $\mathrm{BC}$ addition to soils is unlikely to occur in the short-term, and that the $\mathrm{CEC}$ of $\mathrm{BC}$ can only be increased when the $\mathrm{BC}$ 
Table 3 Minimum and maximum range in cation exchange capacity (CEC) for controls and hydrochar amended soils over the course of the study in Chernozem, Podzol and Gleysol soils

\begin{tabular}{|c|c|c|c|c|c|c|c|c|c|}
\hline \multirow[t]{3}{*}{ Soil } & \multicolumn{4}{|c|}{ Beginning of experiment } & \multicolumn{5}{|c|}{ End of experiment } \\
\hline & \multirow{2}{*}{$\begin{array}{l}T_{0} \\
\text { Control }\end{array}$} & \multicolumn{3}{|l|}{$T_{1}$} & \multicolumn{5}{|l|}{$T_{2}$} \\
\hline & & Coarse & Medium & Fine & Control & Control_pl $^{\mathrm{a}}$ & Coarse & Medium & Fine \\
\hline \multicolumn{10}{|l|}{$\mathrm{cmol} \mathrm{kg}^{-1}$} \\
\hline Chernozem & $38-40.9$ & $38.8-39.7$ & $39.9-40$ & $38.4-39.6$ & $40-40.6$ & $40.2-43.2$ & $40.9-41.4$ & $41-43$ & $42.6-46.6$ \\
\hline Podzol & $17.3-20.2$ & $20.3-21.8$ & $22-22.2$ & $18.6-19.9$ & $19.5-20.7$ & $20-20.6$ & $20.1-21.3$ & $24.2-24.3$ & $19.6-20.2$ \\
\hline Gleysol & $85.5-86.1$ & $84-79.9$ & $84.4-85.3$ & $85.7-89.7$ & $91.9-95.4$ & $94.9-95.2$ & $83.1-85.7$ & $82.6-86.7$ & $87.7-87.7$ \\
\hline
\end{tabular}

$\mathrm{CEC}$ of hydrochar $=28.2 \mathrm{cmol} \mathrm{kg}^{-1}$

${ }^{\mathrm{a}}$ Control with plant

is microbially activated, such as via compositing. Therefore, the addition of an "un-activated" BC would not elevate the CEC. Hale et al. (2013) maintained that soils which are most likely to respond to $\mathrm{BC}$ (and $\mathrm{HC}$ ) addition have a CEC of $\leq 10 \mathrm{cmol} \mathrm{kg}^{-1}$. The initial CEC of the soils of this study were all well above $10 \mathrm{cmol} \mathrm{kg}^{-1}$. Furthermore, the addition of $5 \% \mathrm{HC}$ with a CEC of $28.2 \pm 2.3 \mathrm{cmol} \mathrm{kg}^{-1}$ was insufficient to distinctly increase soil CEC. According to Glaser et al. (2002), a sustainable increase in CEC, as well as the formation of organo-mineral complexes, can be achieved through the formation of carboxylic functional groups on the edges of the aromatic structure of charcoal by means of slow oxidation. It is plausible that the duration of this study may not have been sufficient to allow for such processes to take place.

\subsubsection{Phosphorous $\left(\mathrm{PO}_{4}-\mathrm{P}\right)$}

An adequate supply of all the nutrients plants require is essential for optimum plant growth. However, fertilization practices are concentrated almost exclusively on the supply of $\mathrm{N}, \mathrm{P}$ and $\mathrm{K}$, as these are quantitatively in the highest demand. Fertilization can be achieved by applying mineral and/or organic fertilizers, and additionally, by HC application. A study by Bento et al. (2019) showed that HC released nutrients, however it was dependent on the soil type to which it was applied, as well as the $\mathrm{HC}$ application rate. Although research on this topic is comparatively less than for $\mathrm{BC}$, it can be expected that the fertilizer effect of $\mathrm{HC}$ is even stronger, because the HC structure is less stable (Basso et al. 2013), presumably resulting in greater alteration and enhanced nutrient release.

The results for the beginning of the study $\left(T_{0}\right)$ showed the $\mathrm{PO}_{4}-\mathrm{P}$ content of the controls as $172.4 \pm 7.8 \mathrm{mg} \mathrm{kg}^{-1}$ for the Chernozem; $431.9 \pm 8 \mathrm{mg} \mathrm{kg}^{-1}$ for the Podzol; and $20.9 \pm 1.5 \mathrm{mg} \mathrm{kg}^{-1}$ for the Gleysol (Fig. 3). The $\mathrm{PO}_{4}-\mathrm{P}$ content of the $\mathrm{HC}$ was $2034.6 \pm 38.3 \mathrm{mg} \mathrm{kg}^{-1}$. Shortly after the addition of $\mathrm{HC}\left(T_{1}\right)$, the $\mathrm{PO}_{4}-\mathrm{P}$ content increased in all amended soils, and furthermore, the fine grained
$\mathrm{HC}$ treatments had significantly higher $\mathrm{PO}_{4}-\mathrm{P}$ contents $(p<0.05)$ compared to their respective controls, increasing by $\sim 87 \%, \sim 308 \%$ and $\sim 2500 \%$ in the Chernozem, Podzol and Gleysol, respectively. At the end of the study $\left(T_{2}\right)$, the $\mathrm{PO}_{4}-\mathrm{P}$ content of the $\mathrm{HC}$ amended soils was mostly higher than the controls for all soils, however this was not statistically confirmed, except for the Gleysol fine $(p=0.034)$. Over the course of the study $\left(T_{1}\right.$ to $\left.T_{2}\right)$, the $\mathrm{PO}_{4}-\mathrm{P}$ content mostly decreased for all soils in both the controls, as well as $\mathrm{HC}$ amended samples. This was statistically significant $(p<0.05)$ for all HC amended soils, except for the Chernozem $_{\text {fine }}$, Podzol coarse $_{\text {, }}$

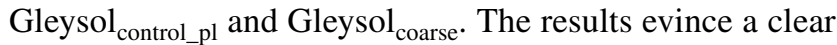
$\mathrm{HC}$ effect on $\mathrm{PO}_{4}-\mathrm{P}$ content, suggesting the $\mathrm{HC}$ acted as a short-term source of $\mathrm{PO}_{4}-\mathrm{P}$ to the soils, with the greatest release of $\mathrm{PO}_{4}-\mathrm{P}$ occurring in the fine grained fraction.

The significant initial increase in $\mathrm{PO}_{4}-\mathrm{P}$ content in all soils compared to the controls was likely derived directly from the HC. This finding is supported by Gronwald et al. (2015), whereby HC produced from digestate feedstock, as in this study, contained 10 times more $\mathrm{P}$ compared to the other feedstocks. It has been shown that BC produced from crop residues and manure feedstocks are more easily decomposable due to their fine nature and high nutrient content. In line with this, a decreased resistance to degradation is most evident in the fine grained HC treatments in this study, which have an inherently larger surface area (compared with larger grain sizes), and consequently showed the highest $\mathrm{PO}_{4}-\mathrm{P}$ release from the $\mathrm{HC}$ at $T_{1}$ and $T_{2}$ in all soils.

Gronwald et al. (2015) and Verheijen et al. (2009) stated that $\mathrm{HC}$ shows a general structurally and chemically induced lower decomposition resistance. The relative ease at which the mineralization of $\mathrm{HC}$ takes place, and the (suggested) ensuing temporary increase in soil microbial activity, is proposed to only occur for as long as the easily mineralized fraction (as DOC) is present in the soil, hence, potentially only over a short-term (Gronwald et al. 2015). This may be a contributing factor to the decreased $\mathrm{PO}_{4}-\mathrm{P}$ content observed from $T_{1}$ to $T_{2}$. A similar finding was reported by Buss et al. (2018), where a reduction in P release from BC 
Fig. 3 Average phosphate content $\left(\mathrm{PO}_{4}-\mathrm{P}\right)$ for the controls and hydrochar grain size treatments in a Chernozem, Podzol and Gleysol over the course of the plant growth experiment. Error bars represent standard deviation of the means. Different letters indicate significant differences in means at $p<0.05$ level between treatments at the respective time periods. $\mathrm{n} . \mathrm{s}=$ nonsignificant. Solid bars indicate significant differences in means $(p<0.05)$ between treatments at the beginning and end of the study. Patterned bars $=$ nonsignificant. Control_ $\mathrm{pl}=$ control with plant. *Statistically significantly difference (not visible)

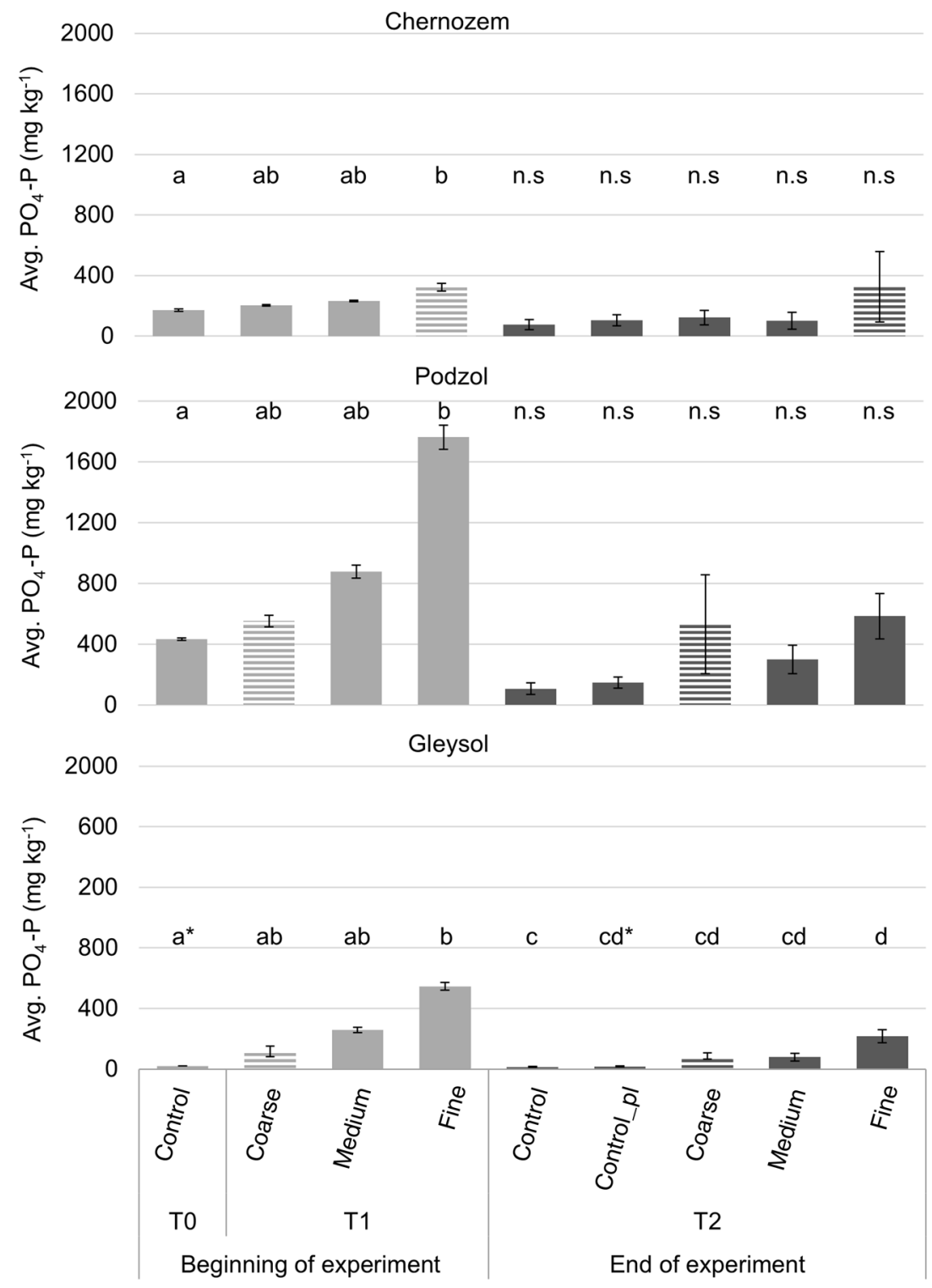

over a series of extractions was observed. Almost $17 \%$ of the total $\mathrm{P}$ content $\left(258 \pm 2.9 \mathrm{mg} \mathrm{kg}^{-1}\right)$ was initially released in the first extraction step, and successively less $\mathrm{P}$ at the second $\left(137 \pm 2.4 \mathrm{mg} \mathrm{kg}^{-1}\right)$ and sixth $\left(34 \pm 0.8 \mathrm{mg} \mathrm{kg}^{-1}\right)$ extraction steps.

Additionally, the $\mathrm{PO}_{4}-\mathrm{P}$ decrease may be related to physicochemical immobilization processes. It is well known that $\mathrm{P}$ contributes to numerous precipitation, mineralization, immobilization and fixation processes, which are further influenced by $\mathrm{pH}$ (Zhang et al. 2016). It has been proposed that increased $\mathrm{PO}_{4}-\mathrm{P}$ content may be caused by the liberation of $\mathrm{P}$ that is affixed to $\mathrm{Fe}$ - and aluminium ( $\mathrm{Al}$ ) oxides in soils as a result of increased $\mathrm{pH}$ due to $\mathrm{BC}$ addition, which effectively increases the availability of $\mathrm{P}$ to microbial communities and plants (Alling et al. 2014; Marmiroli et al. 2018). This liberation is particularly prevalent in acidic soils, whereby the liming effect of the added char acts to lower the $\mathrm{Al}$ and $\mathrm{Fe}$ content of the soil (Biederman and Harpole 2013). This is evident (by the greater increase in $\mathrm{PO}_{4}-\mathrm{P}$ content with $\mathrm{HC}$ addition at $\left.T_{1}\right)$ in the acidic Podzol and Gleysol $\left(T_{0}\right.$ control pH: 5.8 and 4.9, respectively) in this study compared to the smaller increase observed in the more alkaline Chernozem ( $T_{0}$ control $\mathrm{pH}$ : 7.9$)$.

The optimal $\mathrm{pH}$ range for the availability of $\mathrm{P}$ to plants is 6.0-6.5 (Buss et al. 2018), which all soil types were approaching during the course of this study i.e. from $T_{1}$ to $T_{2}$ (see Fig. 3). However, immobilization processes with solid soil compounds cannot be excluded, including those by soil microbes. The transformation of available $\mathrm{P}$ into the microbial biomass (and therefore its immobilization) is strongly dependent on the $\mathrm{C}: \mathrm{P}$ ratio of the soil, whereby an increase in the soil $\mathrm{C}$ content increases $\mathrm{P}$ immobilization by microbes 
(Zhang et al. 2017). It is reasonable to assume that the provision of labile $\mathrm{C}$ compounds to soils by $\mathrm{HC}$ addition likely promoted the incorporation of $\mathrm{P}$ into the microbial biomass by stimulating microbial activity, thus reducing its concentration in the soils.

It is unlikely that precipitation processes played a dominant role in the decreased $\mathrm{PO}_{4}-\mathrm{P}$ content of the soils in this study, since the $\mathrm{pH}$ ranges achieved in all the soils by the addition of $\mathrm{HC}$ favour a reduced solubility of those sorbent ions ( $\mathrm{Fe}, \mathrm{Al}$, and $\mathrm{Ca}$ ), thus also reducing the precipitation of P (Penn and Camberato 2019; Huang et al. 2005; Ifansyah 2013). Therefore, the increased availability of $\mathrm{PO}_{4}-\mathrm{P}$ due to shifting $\mathrm{pH}$ caused by $\mathrm{HC}$ addition during this study, and its subsequent uptake by plants and microbes, are the most likely explanations for the observed decrease in $\mathrm{PO}_{4}-\mathrm{P}$ content from $T_{1}$ to $T_{2}$.

The roles and extent to which the processes of precipitation, inclusion, fixation and adsorption play a part remains open for further research. It can only be stated that the investigated soils in this study should react differently in respect of these processes. However, with regards to the fertilization efficiency of HTC, the results indicate that the HC did not have a medium- or long-term fertilization effect.

\subsubsection{Potassium (K)}

The initial $\mathrm{K}$ content of the controls was $565 \pm 28.2 \mathrm{mg} \mathrm{kg}^{-1}$ for the Chernozem, $69.9 \pm 14.2 \mathrm{mg} \mathrm{kg}^{-1}$ for the Podzol, and $43.9 \pm 0.29 \mathrm{mg} \mathrm{kg}^{-1}$ for the Gleysol (Fig. 4). The K content of the $\mathrm{HC}$ was measured as $2612.5 \pm 268.7 \mathrm{mg} \mathrm{kg}^{-1}$. Shortly after adding $\mathrm{HC}\left(T_{1}\right)$, the $\mathrm{K}$ content increased in all soils compared to the controls, but only the difference between the Podzol control $_{\text {and Podzol }}$ medium was statistically significant $(p=0.034)$. At the end of the study $\left(T_{2}\right)$, there were no significant differences in $\mathrm{K}$ content between the controls and $\mathrm{HC}$ amended soils or between the $\mathrm{HC}$ grain
Fig. 4 Average potassium (K) content for the controls and hydrochar grain size treatments in a Chernozem, Podzol and Gleysol over the course of the plant growth experiment. Error bars represent standard deviation of the means. Different letters indicate significant differences in means at $p<0.05$ level between treatments at the respective time periods. $\mathrm{n} . \mathrm{s}=$ nonsignificant. Solid bars indicate significant differences in means $(p<0.05)$ between treatments at the beginning and end of the study. Patterned bars $=$ nonsignificant. Control_ $\mathrm{pl}=$ control with plant
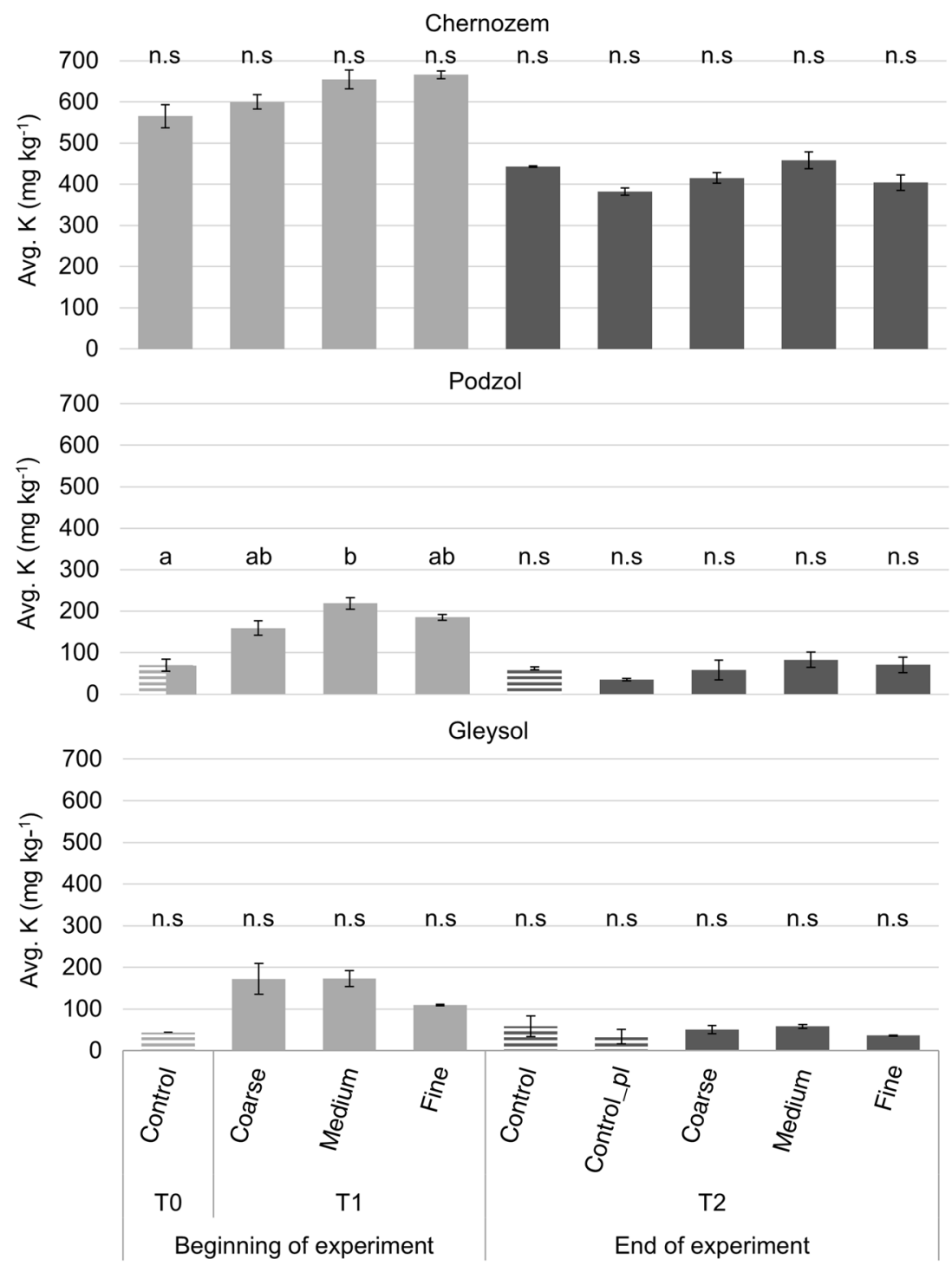
size treatments for all soils. Over the course of the study $\left(T_{1}\right.$ to $\left.T_{2}\right)$, the K content decreased significantly $(p<0.05)$ in all treatments for all soils, except for the Podzol control $_{\text {. }}$ and both Gleysol controls (with and without plants). The addition of $\mathrm{HC}$ resulted in a short-term increase in $\mathrm{K}$ content, thus indicating $\mathrm{HC}$ as a $\mathrm{K}$ source.

The increase in $\mathrm{K}$ content in all $\mathrm{HC}$ amended soils compared to the controls at $T_{1}$ is corroborated by Alling et al. (2014). As argued for $\mathrm{PO}_{4}-\mathrm{P}$ content (see above), it is reasonable to assume that the relatively easily degradable fraction of the $\mathrm{HC}$ is accountable for the quick release of $\mathrm{K}$. As already shown for $\mathrm{PO}_{4}-\mathrm{P}$, the data showed a $\mathrm{K}$ depletion at $T_{2}$. Causation by immobilization via fixation to clays can be excluded in this study, since all soils reacted similarly, and furthermore, contain effectively no clays (Podzol) or consist mainly of micas (Gleysol) (Brümmer and Schroeder 1976), a non-fixing clay mineral. The same may be said for fixation to $\mathrm{HC}$, and hence, plant uptake and/or microbial immobilization are the most probable $\mathrm{K}$ depleting processes, although a definitive explanation cannot be given at this point.

\subsubsection{Mineral nitrogen $\left(\mathrm{N}_{\min }\right)$}

At the beginning of the study $\left(T_{0}\right)$, the Chernozem ${ }_{\text {control }}$ had an average ammonium $\left(\mathrm{NH}_{4}{ }^{+}\right)$content of $1.7 \pm 0.6 \mathrm{mg} \mathrm{kg}^{-1}$; the Podzol $_{\text {control }}: 3.1 \pm 1.5 \mathrm{mg} \mathrm{kg}^{-1}$; and the Gleysol ${ }_{\text {control }}: 6.2 \pm 0.3 \mathrm{mg} \mathrm{kg}^{-1}$. After initially adding the $\mathrm{HC}\left(T_{1}\right)$, which contained $2.7 \% \mathrm{~N}$ (Table 1 ), the $\mathrm{NH}_{4}{ }^{+}$content increased substantially for all soils (Fig. 5), however this increase was only significant $(\mathrm{p}<0.05)$ for the Chernozem medium $(p=0.034), \operatorname{Podzol}_{\text {fine }}(p=0.049)$, and Gleysol ${ }_{\text {coarse }}(p=0.034)$. At the end of the study $\left(T_{2}\right)$, no significant differences in $\mathrm{NH}_{4}{ }^{+}$content between controls and $\mathrm{HC}$ amended soils were observed, except for the Gleysol $_{\text {fine }}(p=0.009)$. Subsequent to the initial increase,
Fig. 5 Average ammonium content (expressed as $\mathrm{NH}_{4}{ }^{+}-\mathrm{N}$ ) for the controls and hydrochar grain size treatments in a Chernozem, Podzol and Gleysol over the course of the plant growth experiment. Error bars represent standard deviation of the means. Different letters indicate significant differences in means at $p<0.05$ level between treatments at the respective time periods. $n . s=$ nonsignificant. Solid bars indicate significant differences in means $(p<0.05)$ between treatments at the beginning and end of the study. Patterned bars $=$ nonsignificant. Control_pl=control with plant. *Statistically significantly difference (not visible on graphic)

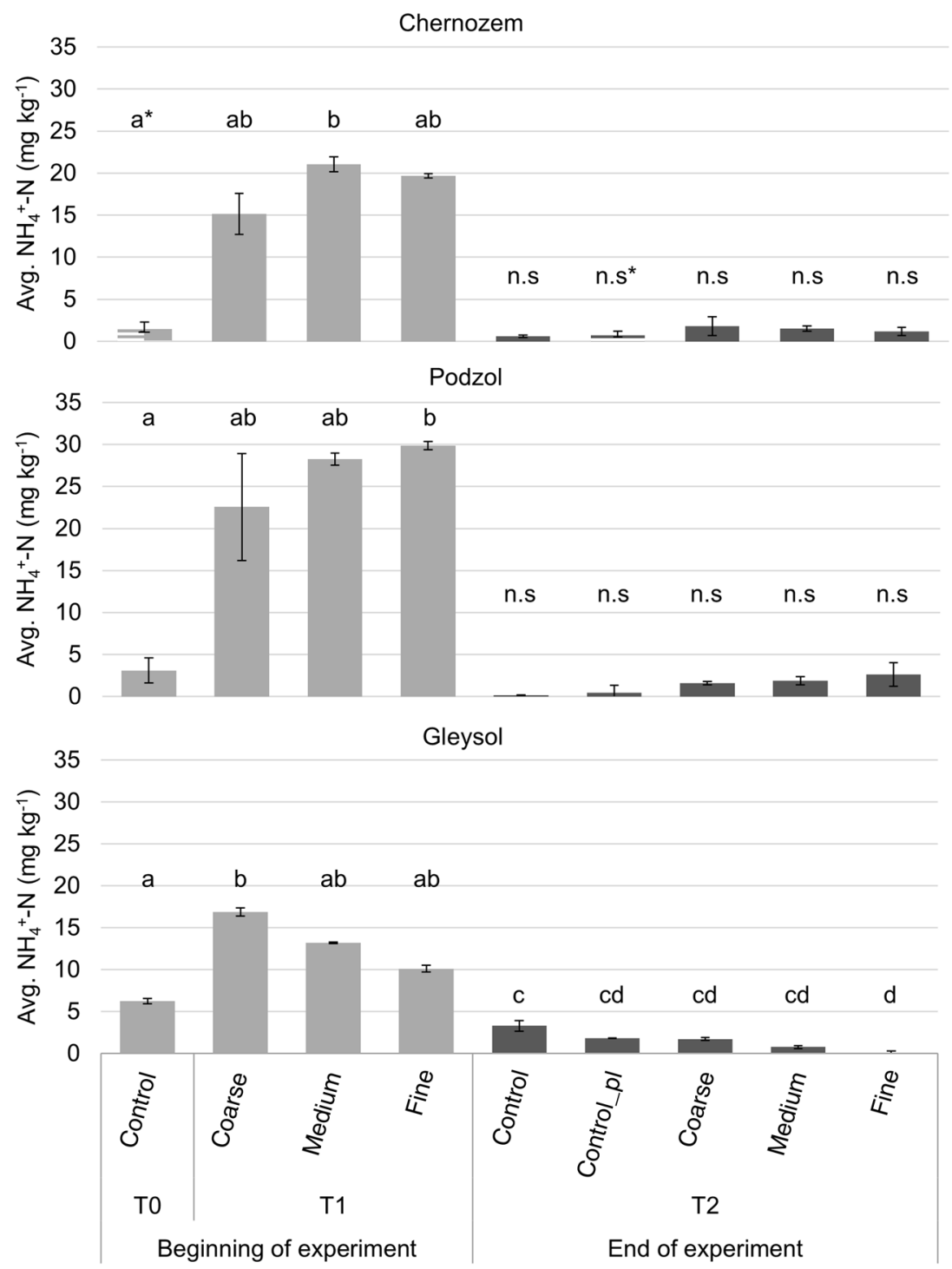


the $\mathrm{NH}_{4}{ }^{+}$content decreased significantly for all soils, except for the Chernozem control_pl $_{\text {and Podzol }}$ control_pl . From the results, it appears that $\mathrm{HC}$ acted as a source of $\mathrm{NH}_{4}{ }^{+}$ for a short time period after application.

At the beginning of the study $\left(T_{0}\right)$, the average nitrate $\left(\mathrm{NO}_{3}{ }^{-}\right)$of the Chernozem control was $25 \pm 2 \mathrm{mg} \mathrm{kg}^{-1}$; $17 \pm 0.2 \mathrm{mg} \mathrm{kg}^{-1}$ for the Podzol ${ }_{\text {control }}$; and $36.5 \pm 0.6 \mathrm{mg} \mathrm{kg}^{-1}$ for the Gleysol ${ }_{\text {control }}$ (Fig. 6). All soils showed a varied response shortly after $\mathrm{HC}$ addition $\left(T_{1}\right)$, however no significant differences were observed. The same varied response between controls and $\mathrm{HC}$ grain size treatments was observed at $T_{2}$. Significant differences in $\mathrm{NO}_{3}{ }^{-}$content occurred from $T_{1}$ to $T_{2}$ for all soils, except for the Chernozem coarse , Podzol $_{\text {control_pl }}$ and Gleysol ${ }_{\text {fine. }}$. However, the soils reacted inconsistently with increasing and decreasing $\mathrm{NO}_{3}{ }^{-}$content.
Consequently, a relationship between $\mathrm{HC}$ and $\mathrm{NO}_{3}{ }^{-}$content was indeterminable.

Tambone and Adani (2017) compared a digestate produced by anaerobic digestion to compost and sewage sludge, and found that the digestate had the highest $\mathrm{N}$ content (157.2 $\mathrm{k} \mathrm{kg}^{-1}$ dry mass), of which $\sim 80 \%$ occurred as $\mathrm{NH}_{4}{ }^{+}$. The $\mathrm{HC}$ used in this study may therefore have a similarly high initial $\mathrm{NH}_{4}{ }^{+}$content, which, as is suggested for $\mathrm{PO}_{4}-\mathrm{P}$ and $\mathrm{K}$, may have been released directly into the soil solution; thereby substantially increasing the $\mathrm{NH}_{4}{ }^{+}$content of the $\mathrm{HC}$ amended soils at $T_{1}$. This is substantiated by the $\mathrm{C} / \mathrm{N}$ ratio of the HC used in this study (15.2) (refer to Table 1), whereby a $\mathrm{C} / \mathrm{N}$ ratio $<20$ indicates $\mathrm{N}$ mineralization (ammonification), and therefore the release of $\mathrm{N}$ from the $\mathrm{HC}$ (Dieguez-Alonso et al. 2018; Hagemann et al. 2016). However, as already stated for $\mathrm{PO}_{4}-\mathrm{P}$ and $\mathrm{K}$, the relatively easily mineralized
Fig. 6 Average nitrate content (expressed as $\mathrm{NO}_{3}{ }^{-} \mathrm{N}$ ) for the controls and hydrochar grain size treatments in a Chernozem, Podzol and Gleysol over the course of the plant growth experiment. Error bars represent standard deviation of the means. Different letters indicate significant differences in means at $p<0.05$ level between treatments at the respective time periods. n.s $=$ nonsignificant. Solid bars indicate significant differences in means $(p<0.05)$ between treatments at the beginning and end of the study. Patterned bars = nonsignificant. Control_pl = control with plant

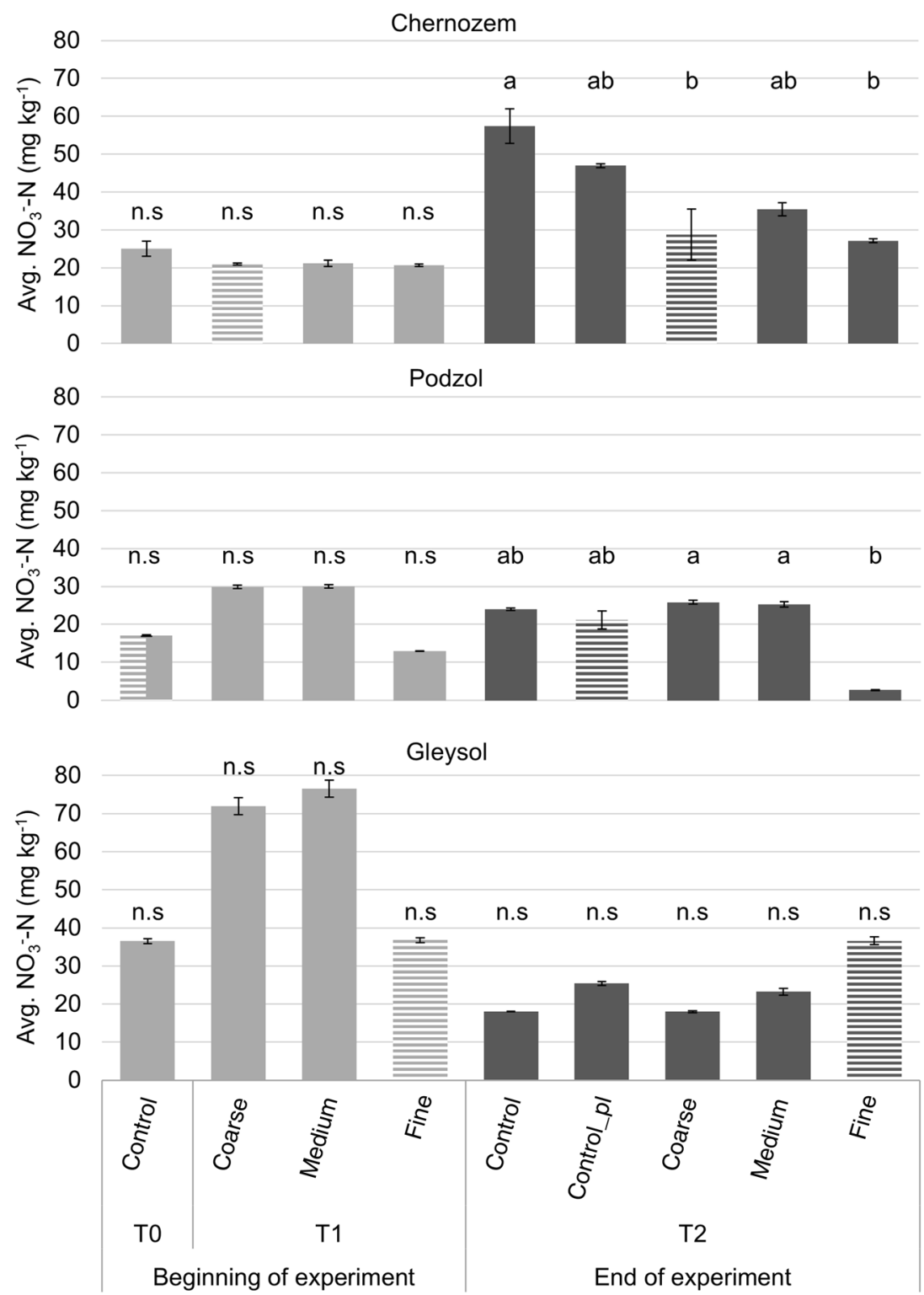


fraction of $\mathrm{HC}$ resulted in only a short-term release of nutrients (Gronwald et al. 2015), which was subsequently further rapidly processed within the food chain (Libra et al. 2011). In Bargmann et al. (2013a), the $\mathrm{N}$ content measured in the microbial biomass present in $\mathrm{HC}$ amended soils was found to be proportionate to the decreased $\mathrm{N}$ content of the incubated soils.

According to Tambone and Adani (2017), nitrification is likely responsible for the decreasing $\mathrm{NH}_{4}{ }^{+}$concentration in soils, however, the associated $\mathrm{NO}_{3}{ }^{-}$results of this study do not comply with this explanation. Although it is probable that nitrification took place from $T_{1}$ to $T_{2}$, the noncontinuous analysis during the course of the study resulted in this process going undetected. The results imply that the $\mathrm{NO}_{3}{ }^{-}$content, which has a higher susceptibility to change compared to the other measured plant available nutrients, responded more strongly to the micro-environmental conditions within the pots, such as the microbial activity and communities, temperature and moisture content, and the original soil organic matter (SOM) content of the different soil types (Hagemann et al. 2016). This finding is supported by Sun et al. (2014), who found that the interaction between BC and nitrification is multifactorial.

\subsection{Effect of hydrochar application on plant growth dynamics of Chinese cabbage}

\subsubsection{Seed germination}

The germination success of the controls was, on average, $53 \%$ for the Chernozem, $84 \%$ for the Podzol, and $76 \%$ for the Gleysol (Table 4). Despite a varied response of the soils to $\mathrm{HC}$ addition between round 1 and 2, and independent of $\mathrm{HC}$ grain size; the average germination success for the $\mathrm{HC}$ amended soils over the course of the experiment was in a similar range as the controls, with the Chernozem showing a germination rate of $56 \%$, the Podzol $75 \%$, and the Gleysol $60 \%$. Hence, on average, the addition of $\mathrm{HC}$ did not inhibit the germination of Chinese cabbage seeds in any soils.

The reduction in germination rate in the Chernozem and Podzol from round one to round two, and the increase in the Gleysol, occur in both the controls and the HC amended soils, which indicates an environmental influence in combination with soil specific factors. The differences in the properties of the three soil types, such as texture, aggregate stability and WHC resulted in varied responses to potential environmental fluctuations, including increasing temperature. In the area in which the study was conducted, the temperature increased from an avg. of $\sim 1{ }^{\circ} \mathrm{C}$ in February 2018 at the beginning of the study to $\sim 13{ }^{\circ} \mathrm{C}$ by the end of the germination experiment in April 2018 (temperatures measured at 32 m height; Kock 2019). Such increased temperatures over this time may have caused a greater level of desiccation in the Chernozem and Podzol due to lower WHC compared to the Gleysol (see Table 2), which reduced the rate of seed germination in the Chernozem and Podzol in the second round of the experiment.

However, the overall lack of germination inhibition exhibited in this study contradicts existing literature, which states that the addition of a fresh and/or non-pretreated HC to soils delays or severely inhibits seed germination and plant growth. This inhibition is attributed to the organic contaminants inherent in the $\mathrm{HC}$, such as phenols and organic acids (Bargmann et al. 2013b, 2014a; Röhrdanz et al. 2019), particularly at concentrations above $10 \%$ (w/w) (Bargmann et al. 2013b, 2014a; Busch et al. 2012). The HTC temperature and reaction time used in this study $\left(\sim 200{ }^{\circ} \mathrm{C}\right.$ for ca. $3 \mathrm{~h}$ ) may have been sufficiently high and long in duration to remove the volatile compounds that are potentially harmful for germination and plant growth (Reza et al. 2014), or the free gas exchange at the soil-atmosphere interface allowed for the quick release of these substances. The latter is supported by Sun et al. (2014), in which the potential to improve soil aeration was evinced by an enhanced soil porosity following BC addition, which further increased gas diffusion.

This study's finding are corroborated by Fang et al. (2015), where the addition of $\mathrm{HC}$ produced at $200{ }^{\circ} \mathrm{C}$ yielded similar results for seedling growth to that of the control treatment. Puccini et al. (2018) found a reduction in the volatile fatty acid (98\%), total polyphenol $(41 \%)$ and total tannins (37\%) contents of a $\mathrm{HC}$ after aging for 4 months under room temperature and free air exchange conditions. This aged HC showed the highest seed germination success of lettuce, compared to the fresh and washed HC. As such, the findings of this study may be the result of the relatively advanced age of the $\mathrm{HC}$ (at
Table 4 Percentage germinated seeds for the controls and hydrochar amended soils over two rounds of the germination experiment conducted in a Chernozem, Podzol and Gleysol

\begin{tabular}{|c|c|c|c|c|c|c|}
\hline \multirow[t]{2}{*}{ Soil } & \multicolumn{3}{|l|}{ Control } & \multicolumn{3}{|c|}{ Hydrochar amended soil } \\
\hline & $\begin{array}{l}\text { Round } 1 \\
(\%)\end{array}$ & Round 2 & Average & Round 1 & Round 2 & Average \\
\hline Chernozem & 94 & 12 & 53 & 85 & 28 & 56 \\
\hline Podzol & 95 & 73 & 84 & 84 & 66 & 75 \\
\hline Gleysol & 73 & 78 & 76 & 34 & 86 & 60 \\
\hline
\end{tabular}




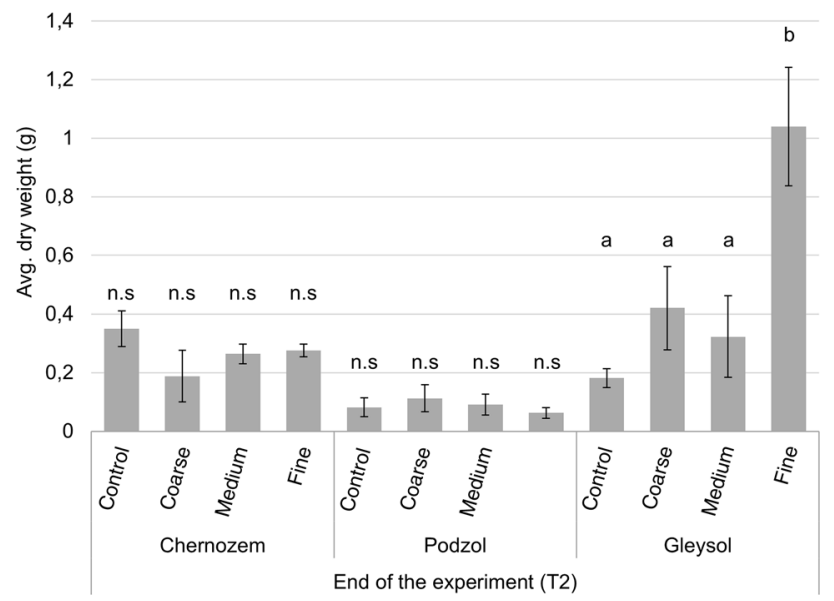

Fig. 7 Biomass production of Chinese cabbage for the controls and hydrochar grain size treatments in a Chernozem, Podzol and Gleysol [expressed in mean dry weight (g)]. Error bars represent a 99\% confidence level. Different letters indicate significant differences in means; n.s $=$ nonsignificant

least $>3$ months) and storage time (Bargmann et al. 2013b, 2014a), as well as the relatively low concentration of HC (5\%) applied to the soils, which supposedly rendered the typically adverse impacts of $\mathrm{HC}$ on germination ineffective.

\subsubsection{Biomass}

With the exception of the Gleysol $_{\text {fine }}$, there were no significant differences in biomass production between $\mathrm{HC}$ amended soils and the controls, nor between $\mathrm{HC}$ grain size treatments in all soils (Fig. 7). Therefore, it can be generalized from the results that the addition of $\mathrm{HC}$ to the soils showed no positive or negative influence on plant growth.

The results are corroborated by Bargmann et al. (2014a) and Röhrdanz et al. (2019), who also found that the addition of untreated $\mathrm{HC}$ had little influence on the growth of Chinese cabbage. The age of the HC, its low concentration in the soils, the release of volatile compounds in open-air conditions (Bargmann et al. 2013b) and/or HTC production conditions may all contribute to these findings. Furthermore, Bargmann et al. (2014a) postulated that the absence of negative $\mathrm{HC}$ influence may have been due to microbial activity, which acted to decompose the harmful phytotoxic compounds in the HC, and thereby allow for favourable plant growth conditions. The significantly higher biomass production in the Gleysol fine $_{\text {may be due }}$ to a combined effect of the higher WHC of the Gleysol compared to the other soil types, and the relatively easily degradable fraction of $\mathrm{HC}$, as previously mentioned, which allowed for the release of essential nutrients for plant growth, particularly for the fine grained $\mathrm{HC}$ particles due to their inherently larger surface area, which is more vulnerable to degradation.

\section{Conclusion}

The addition of $5 \% \mathrm{HC}$ from digestate feedstock resulted in a short-term supply of nutrients $\left(\mathrm{PO}_{4}-\mathrm{P}, \mathrm{K}_{\text {and }} \mathrm{NH}_{4}{ }^{+}\right)$to all the soils, which was most significant in the finer grained fractions. This finding exemplifies the fertilization effect of HC. Importantly, the quick release and transient nature of this effect was likely due to the increased rate of decomposition as a result of the less stable $\mathrm{C}$ structure of the $\mathrm{HC}$ and its more labile $\mathrm{C}$ species relative to $\mathrm{BC}$. However, the effects of $\mathrm{HC}$ on the biomass production of Chinese cabbage, WHC, aggregate stability and CEC were minor or intangible.

The fertilization effect of the $\mathrm{HC}$ was associated with a persistent compensatory shift in soil $\mathrm{pH}$ toward the $\mathrm{pH}$ of the $\mathrm{HC}$, which was most pronounced in the finer grained $\mathrm{HC}$ treatments. Hence, the application of HC could partially substitute lime supply. Additionally, the observed $\mathrm{pH}$ shift provoked an intensified $\mathrm{PO}_{4}-\mathrm{P}$ solubility. On the other hand, the increased $\mathrm{pH}$ might favour SOM mineralization, a rather undesired impact, especially for sandy soils. A positive effect was found for seed germination. Contrary to other studies (Bargmann et al. 2013b, 2014a; Busch et al. 2012), no germination inhibition occurred which means that $5 \% \mathrm{HC}$ application can be implemented without inducing harmful consequences for plant growth. The Chinese cabbage grew satisfyingly, however there was no further improvement compared to the controls.

It may therefore be concluded that the digestate feedstock was successfully converted into a useful product for soil amendment. The 5\% HC application did not induce detrimental $\mathrm{pH}$ shifts and acted as a short-term fertilizer. However, it was unable to sustain the supply of nutrients at levels necessary to enhance plant growth and would therefore not be suitable as a long-term fertilizer in its present form. Nonetheless, its readily available high nutrient content, particularly in fine grained fractions, could have the potential as a replacement for traditional $\mathrm{P}$ and $\mathrm{K}$ fertilizers. Therefore, further research is necessary for this potential to be realised.

Acknowledgements Open Access funding provided by Projekt DEAL. This study was conducted under the auspices of the Circular BIOmass CAScade to $100 \%$ (BIOCAS) project, which is funded by the European Union Interreg North Sea Region Project 38-2-4-17. We would like to thank the students of the Soil Science working group who provided analytical assistance, as well as Thomas Pollmann for his support and consultation.

Open Access This article is licensed under a Creative Commons Attribution 4.0 International License, which permits use, sharing, adaptation, distribution and reproduction in any medium or format, as long as you give appropriate credit to the original author(s) and the source, provide a link to the Creative Commons licence, and indicate if changes 
were made. The images or other third party material in this article are included in the article's Creative Commons licence, unless indicated otherwise in a credit line to the material. If material is not included in the article's Creative Commons licence and your intended use is not permitted by statutory regulation or exceeds the permitted use, you will need to obtain permission directly from the copyright holder. To view a copy of this licence, visit http://creativecommons.org/licenses/by/4.0/.

\section{References}

Abel S, Peters A, Trinks S, Schonsky H, Facklam M, Wessolek G (2013) Impact of biochar and hydrochar addition on water retention and water repellency of sandy soil. Geoderma 202-203:183-191

Alef K (1991) Methodenhandbuch bodenmikrobiologie: aktivitäten, biomasse, differenzierung. Ecomed Verlagsgesellschaft mbH, Landsberg/Lech

Alling V, Hale SE, Martinsen V, Mulder J, Smebye A, Breedveld GD, Cornelissen $\mathrm{G}$ (2014) The role of biochar in retaining nutrients in amended tropical soils. J Plant Nutr Soil Sci 177:671-680

Bargmann I, Martens R, Rillig MC, Kruse A, Kücke M (2013a) Hydrochar amendment promotes microbial immobilization of mineral nitrogen. J Plant Nutr Soil Sci 177:59-67

Bargmann I, Rillig MC, Buss W, Kruse A, Kücke M (2013b) Hydrochar and biochar effects on germination of spring barley. J Agron Crop Sci 199:360-373

Bargmann I, Rillig MC, Kruse A, Greef J-M, Kücke M (2014a) Effects of hydrochar application on the dynamics of soluble nitrogen in soils and on plant availability. J Plant Nutr Soil Sci 177:48-58

Bargmann I, Rillig MC, Kruse A, Greef J-M, Kücke M (2014b) Initial and subsequent effects of hydrochar amendment on germination and nitrogen uptake of spring barley. J Plant Nutr Soil Sci 177:68-74

Baronti S, Alberti G, Camin F, Criscuoli I, Genesio L, Mass R, Vaccari FP, Ziller L, Miglietta F (2017) Hydrochar enhances growth of poplar for bioenergy while marginally contributing to direct soil carbon sequestration. GCB Bioenergy 9:1618-1626

Basso D, Castello D, Baratieri M, Fiori L (2013) Hydrothermal carbonization of waste biomass: progress report and prospects. In: 21st European Biomass Conference and Exhibition, 3-7 June, Copenhagen, Denmark, pp 1478-1487

Bento LR, Castro AJR, Moreira AB, Ferreira OP, Bisinoti MC, Melo CA (2019) Release of nutrients and organic carbon in different soil types from hydrochar obtained using sugarcane bagasse and vinasse. Geoderma 334:24-32

Berge ND, Kammann C, Ro K, Libra J (2013) Environmental applications of hydrothermal carbonization technology: biochar production, carbon sequestration, and waste conversion. In: Titirici M-M (ed) Sustainable carbon materials from hydrothermal processes. Wiley, London, pp 295-329

Biederman LA, Harpole SW (2013) Biochar and its effects on plant productivity and nutrient cycling: a meta-analysis. GCB Bioenergy 5:202-214

Blanco-Canqui H (2017) Biochar and soil physical properties. Soil Sci Soc Am J 81:687-711

Brodowski S, Amelung W, Haumaier L, Abetz C, Zech W (2005) Morphological and chemical properties of black carbon in physical soil fractions as revealed by scanning electron microscopy and energy- dispersive X-ray spectroscopy. Geoderma 128:116-129

Brümmer G, Schroeder D (1976) Bestand, Umwandlung und Neubildung von Tonmineralen in küstennahen Sedimenten der Nordsee. Meyniana 28:19-28
Busch D, Glaser B (2015) Stability of co-composted hydrochar and biochar under field conditions in a temperate soil. Soil Use Manage 31:251-258

Busch D, Kammann C, Grünhage L, Müller C (2012) Simple biotoxicity tests for evaluation of carbonaceous soil additives: establishment and reproducibility of four test procedures. J Environ Qual 41:1023-1032

Buss W, Assavavittayanon K, Shepherd JG, Heal KV, Sohi S (2018) Biochar phosphorous release is limited by high $\mathrm{pH}$ and excess calcium. J Environ Qual 47:1298-1303

de Jesus Duarte S, Glaser B, Pellegrino Cerri CE (2019) Effect of biochar particle size on physical, hydrological and chemical properties of loamy and sandy tropical soils. Agronomy 9:165

Dieguez-Alonso A, Funke A, Anca-Couce A, Rombolà AG, Ojeda G, Bachmann J, Behrendt F (2018) Towards biochar and hydrochar engineering-influence of process conditions on surface physical and chemical properties, thermal stability, nutrient availability, toxicity and wettability. Energies 11:496

Domingues RR, Trugilho PF, Silva CA, de Melo ICNA, Melo LCA, Magriotis ZM, Sánchez-Monedero MA (2017) Properties of biochar derived from wood and high-nutrient biomasses with the aim of agronomic and environmental benefits. PLoS One 12:e0176884

Downie A, Crosky A, Munroe P (2009) Physical properties of biochar. In: Lehmann J, Joseph S (eds) Biochar for environmental management: science and technology. Earthscan, London, pp 13-32

Dunn OJ (1964) Multiple comparisons using rank sums. Technometrics 6:241-252

Eibisch N, Helfrich M, Don A, Mikutta R, Kruse A, Ellerbrock R, Flessa H (2013) Properties and degradability of hydrothermal carbonization products. J Environ Qual 42:1565-1573

Eskandari S, Mohammadi A, Sandberg M, Eckstein RL, Hedberg K, Granström (2019) Hydrochar-amended substrates for production of containerized pine tree seedlings under different fertilization regimes. Agronomy 9:350

Fang J, Gao B, Chen J, Zimmerman AR (2015) Hydrochars derived from plant biomass under various conditions: characterization and potential applications and impacts. Chem Eng J 267:253-259

Fiori L, Basso D, Castello D, Baratieri M (2014) Hydrothermal carbonization of biomass: design of a batch reactor and preliminary experimental results. Chem Eng Trans 37:55-60

Garlapalli RK, Wirth B, Reza MT (2016) Pyrolysis of hydrochar from digestate: effect of hydrothermal carbonization and pyrolysis temperatures on pyrochar formation. Bioresour Technol 220:168-174

Głąb T, Palmowska J, Zaleski T, Gondek K (2016) Effect of biochar application on soil hydrological properties and physical quality of sandy soil. Geoderma 281:11-20

Glaser B, Lehmann J, Zech W (2002) Ameliorating physical and chemical properties of highly weathered soils in the tropics with charcoal—a review. Biol Fertil Soils 35:219-230

Greenberg I, Kaiser M, Gunina A, Ledesma P, Polifka S, Wiedner K, Mueller CW, Glaser B, Ludwig B (2019) Substitution of mineral fertilizers with biogas digestate plus biochar increases physically stabilized soil carbon but not crop biomass in a field trial. Sci Total Environ 680:181-189

Gronwald M, Don A, Tiemeyer B, Halfrich M (2015) Effects of fresh and aged chars from pyrolysis and hydrothermal carbonization on nutrient sorption in agricultural soils. Soil 1:475-489

Hagemann N, Harter J, Behrens S (2016) Elucidating the impacts of biochar applications on nitrogen cycling microbial communities. In: Ralebitso-Senior TK, Orr CH (eds) Biochar application: essential soil microbial ecology. Elsevier, Amsterdam, pp 163-198

Hale SE, Alling V, Martinsen V, Mulder J, Breedveld GD, Cornelissen G (2013) The sorption and desorption of phosphate-P, ammonium-N and nitrate- $\mathrm{N}$ in cacao shell and corn cob biochars. Chemosphere 91:1612-1619 
Handbuch Forstliche Analytik (2005) Potentielle Kationenaustauschkapazität, DIN ISO 13536:1997-04, Eine Loseblatt-Sammlung der Analysemethoden im Forstbereich, Gutachterausschuss Forstliche Analytik (Hg), 1. Ergänzung (June 2005). https://www.bmel.de/ SharedDocs/Downloads/Landwirtschaft/Wald-Jagd/Bodenzusta ndserhebung/Handbuch/Z-Ergaenzung 1.pdf?__blob=publicatio nFile. Accessed 27 June 2019

Hao S, Zhu X, Liu Y, Qian F, Fang Z, Shi Q, Zhang S, Chen J, Ren ZJ (2018) Production temperature effects on the structure of hydrochar-derived dissolved organic matter and associated toxicity. Environ Sci Technol 52:7486-7495

Huang Q, Wang Z, Wang C, Wang S, Jin X (2005) Phosphorus release in response to $\mathrm{pH}$ variation in the lake sediments with different ratios of iron-bound $\mathrm{P}$ to calcium-bound $\mathrm{P}$. Chem Spec Bioavailabil 17(2):55-61

Ifansyah H (2013) Soil pH and solubility of aluminum, iron, and phosphorus in Ultisols: the roles of humic acid. J Trop Soils 18(3):203-208

Jones NF, Pejchar L, Kiesecker JM (2015) The energy footprint: how oil, natural gas, and wind energy affect land for biodiversity and the flow of ecosystem services. Bioscience 65:290-301

Kalinina O, Krause S-E, Goryachkin SV, Karavaeva NA, Lyuri DI, Giani L (2011) Self-restoration of post-agrogenic Chernozems of Russia: soil development, carbon stocks, and dynamics of carbon pools. Geoderma 162:196-206

Kambo HS, Dutta A (2015) A comparative review of biochar and hydrochar in terms of production, physico-chemical properties and applications. Renew Sust Energ Rev 45:359-378

Kock D (2019) Aktuelles Wetter/Klimawerte. Carl Von Ossietzky Universität Oldenburg. https://uol.de/wetter. Accessed 26 Nov 2019

Laerd Statistics (2015) Kruskal-Wallis H Test using SPSS Statistics. Statistical tutorials and software guides. http://statistics/laerd .com/. Accessed 16 Aug 2019

Lehmann J, Rondon M (2006) Bio-char soil management on highly weathered soils in the humid tropics. In: Uphoff N, Ball AS, Fernandes E, Herren H, Husson O, Laing M, Palm C, Pretty J, Sánchez P, Sanginga N, Thies J (eds) Biological approaches to sustainable soil systems. CRC, Boca Raton, pp 517-530

Lehmann J, Gaunt J, Rondon M (2006) Bio-char sequestration in terrestrial ecosystems-a review. Mitigation adapt. Strateg Glob Change 11:403-427

Liao W, Thomas SC (2019) Biochar particle size and post-pyrolysis mechanical processing affect soil $\mathrm{pH}$, water retention capacity, and plant performance. Soil Syst 3:14

Libra JA, Ro KS, Kammann C, Funke A, Berge ND, Neubauer Y, Titirici M-M, Fühner C, Bens O, Kern J, Emmerich K-H (2011) Hydrothermal carbonisation of biomass residuals: a comparative review of the chemistry, processes and applications of wet and dry pyrolysis. BioFuels 2:71-106

Liu Z, Dugan B, Masiello CA, Gonnermann HM (2017) Biochar particle size, shape, and porosity act together to influence soil water properties. PLoS One 12:1-19

Malghani S, Jüschke E, Baumert J, Thuille A, Antonietti M, Trumbore S, Gleixner G (2015) Carbon sequestration potential of hydrothermal carbonization char (hydrochar) in two contrasting soils; results of a 1-year field study. Biol Fertil Soils 51:123-134

Marchetti R, Castelli F (2013) Biochar from swine solids and digestate influence nutrient dynamics and carbon dioxide release in soil. J Environ Qual 42:893-901

Marmiroli M, Bonas U, Imperiale D, Lencioni G, Mussi F, Marmiroli N, Maestri E (2018) Structural and functional features of chars from different biomasses as potential plant amendments. Front Plant Sci 9:1119

Monlau F, Sambusiti C, Ficara E, Aboulkas A, Barakat A, Carrère $H$ (2015) New opportunities for agricultural digestate valorization: current situation and perspectives. Energy Environ Sci 8:2600-2621

Mukherjee S, Weihermueller L, Tappe W, Vereechen H, Burauel P (2016) Microbial respiration of biochar- and digestate-based mixtures. Biol Fertil Soils 52:151-164

Nimmo JR, Perkins KS (2002) Aggregation stability and size distribution. In: Dane JH, Topp GC (eds) Methods of soil analysis, Part 4-Physical methods. Soil Sci Soc Am, Madison, pp 317-328

Penn CJ, Camberato JJ (2019) A Critical review on soil chemical processes that control how soil $\mathrm{pH}$ affects phosphorous availability to plants. Agriculture 9(6):120

Pituello C, Dal Ferro N, Francioso O, Simonetti G, Berti A, Piccoli I, Pisi A, Morari F (2018) Effects of biochar on the dynamics of aggregate stability in clay and sandy loam soils. Eur J Soil Sci 69(5):827-842

Prayogo C, Jones JE, Baeyens J, Bending GD (2014) Impact of biochar on mineralisation of $\mathrm{C}$ and $\mathrm{N}$ from soil and willow litter and its relationship with microbial community biomass and structure. Biol Fertil Soils 50:695-702

Puccini M, Ceccarini L, Antichi D, Seggiani M, Tavarini S, Latorre MH, Vitolo S (2018) Hydrothermal carbonization of municipal woody and herbaceous prunings: hydrochar valorisation as soil amendment and growth medium for horticulture. Sustainability. 10:846

Reza MT, Andert J, Wirth B, Busch D, Pielert J, Lynam JG, Mumme J (2014) Hydrothermal carbonisation of biomass for energy and crop production. Appl Bioenergy 1:11-29

Röhrdanz M, Rebling T, Ohlert J, Jasper J, Greve T, Buchwald R, von Frieling P, Wark M (2016) Hydrothermal carbonisation of biomass from landscape management- Influence of process parameters on soil properties of hydrochars. J Environ Manage 173:72-78

Röhrdanz M, Greve T, de Jager M, Buchwald R, Wark R (2019) Cocomposted hydrochar substrates as growing media for horticultural crops. Sci Hortic 252:96-103

Salem MSA (2013) Soil biota interactions with hydrochar. $\mathrm{PhD}$ thesis, Freie Universität Berlin, Germany

Sänger-von Open P, Nack T, Nixdorf J, Mencke B (1993) Vorstellung der $\mathrm{SrCl}_{2}$-Methode nach Bach zur Bestimmung der effektiven Austauschkapazität und Vergleich mit der $\mathrm{NH}_{4} \mathrm{Cl}$-Methode, in Zeitschrift für Pflanzenernährung und Bodenkunde, 156, pp $311-316$

Schimmelpfennig S, Müller C, Grünhage L, Koch C, Kammann C (2014) Biochar, hydrochar and uncarbonized feedstock application to permanent grassland-Effects on greenhouse gas emissions and plant growth. Agric Ecosyst Environ 191:39-52

Schröter F (2018) The production of porous hydrochars. Unpublished $\mathrm{PhD}$ thesis, Carl von Ossietzky Universität, Germany

Schulz H, Glaser B (2012) Effects of biochar compared to organic and inorganic fertilizers on soil quality and plant growth in a greenhouse experiment. J Plant Nutr Soil Sci 175:410-422

Septien S, Sanz FJE, Salvador S, Valin S (2018) The effect of pyrolysis heating rate on the steam gasification reactivity of char from woodchips. Energy 142:68-78

Six J, Paustian K, Elliot ET, Combrink C (2000) Soil structure and organic matter. Soil Sci Soc Am J 64:681-689

Sombroek WG, Nachtergaele FO, Hebel A (1993) Amounts, dynamics and sequestering of carbon in tropical and subtropical soils. Ambio 22:417-426

Steiner C, Garcia M, Zech W (2009a) Effects of charcoal as slow release nutrient carrier on N-P-K dynamics and soil microbial population: pot experiments with ferralsol substrate. In: Woods WI, Teixeira WG, Lehmann J, Steiner C, WinklerPrins A, Rebellato L (eds) Amazonian dark earths: wim Sombroek's vision. Springer, Dordrecht, pp 325-328

Steiner C, Teixeira WG, Woods WI, Zech W (2009b) Indigenous knowledge about terra preta formation. In: Woods WI, Teixeira 
WG, Lehmann J, Steiner C, WinklerPrins A, Rebellato L (eds) Amazonian dark earths: Wim Sombroek's vision. Springer, Dordrecht, pp 193-204

Sun F, Lu S (2014) Biochars improve aggregate stability, water retention, and pore-space properties of clayey soil. J Plant Nutr Soil Sci 177:26-33

Sun Z, Bruun EW, Arthur E, de Jonge LW, Moldrup P, HauggaardNielsen H, Elsgaard L (2014) Effect of biochar on aerobic processes, enzyme activity, and crop yields in two sandy loam soils. Biol Fertil Soils 50:1087-1097

Tambone F, Adani F (2017) Nitrogen mineralization from digestate in comparison to sewage sludge, compost and urea in a laboratory incubated soil experiment. J Plant Nutr Soil Sci 180:335-365

Theuerl S, Herrmann C, Heiermann M, Grundmann P, Landwehr N, Kreidenweis U, Prochnow A (2019) The future agricultural biogas plant in Germany: a vision. Energies 12(3):396

VDLUFA (Verband Deutscher Landwirtschaftlicher Untersuchungsund Forschungsanstalten $(\mathrm{Hg})$ (2002) Bestimmung von mineralischem Stickstoff (Nitrat und Ammonium) in Bodenprofilen (Nmin-Labormethode), Die Untersuchung von Böden, A 6.1.4.1, VDLUFA Methodenbuch I, 3. Teillieferung, VDLUFA-Verlag. https://www.vdlufa.de/Methodenbuch/index.php?option=com content\&view $=$ article\&id $=2065 \&$ lang $=$ de. Accessed 27 June 2019

VDLUFA (Verband Deutscher Landwirtschaftlicher Untersuchungs- und Forschungsanstalten (Hg) (2012a) Bestimmung der Kationenaustauschkapazität und der austauschbaren Kationen mit Calcit-gesättigter Haxammincobalt-Trichlorid-Lösung, Die Untersuchung von Böden, A 9.1.1.1, VDLUFA Methodenbuch I, 6. Teillieferung, VDLUFA-Verlag. https://www.vdlufa.de/ Methodenbuch/index.php?option=com_content $\&$ view $=$ artic le\&id=7\&Itemid=108\&lang=de. Accessed 27 June 2019
VDLUFA (Verband Deutscher Landwirtschaftlicher Untersuchungsund Forschungsanstalten $(\mathrm{Hg})$ (2012b) Bestimmung von Phosphor und Kalium im Calcium-Acetate-Lactat-Auszug, Die Untersuchung von Böden, A 6.2.1.1, VDLUFA Methodenbuch I, 6. Teillieferung, VDLUFA-Verlag. https://www.vdlufa.de/ Methodenbuch/index.php?option $=$ com_content $\&$ view $=$ artic le\&id=2072\&lang=de. Accessed 27 June 2019

Verheijen FGA, Jeffrey S, Bastos AC, van der Velde M, Diafas I (2009) Biochar application to soils: A critical scientific review of effects on soil properties, processes and functions. EUR 24099 EN, Office for the Official Publications of the European Communities, Luxembourg

WinklerPrins AMGA (2014) Terra Preta: the mysterious soils of the Amazon. In: Churchman GJ, Landa ER (eds) The soils underfoot: infinite possibilities for a finite resource. Taylor \& Francis, Florida, pp 235-245

Woolf D, Amonette JE, Street-Perrott FA, Lehmann J, Joseph S (2010) Sustainable biochar to mitigate global climate change. Nat Commun 1:1-9

Zhang B, von Keitz M, Valentas K (2008) Thermal effects on hydrothermal biomass liquefaction. Appl Biochem Biotechnol 147:143-150

Zhang H, Chen C, Gray EM, Boyd SE, Yang H, Zhang D (2016) Roles of biochar in improving phosphorous availability in soils: a phosphate adsorbent and a source of available phosphorous. Geoderma 276:1-6

Zhang X, Zhang L, Li A (2017) Hydrothermal co-carbonization of sewage sludge and pinewood sawdust for nutrient-rich hydrochar production: synergistic effects and products characterization. J Environ Manage 201:52-62 